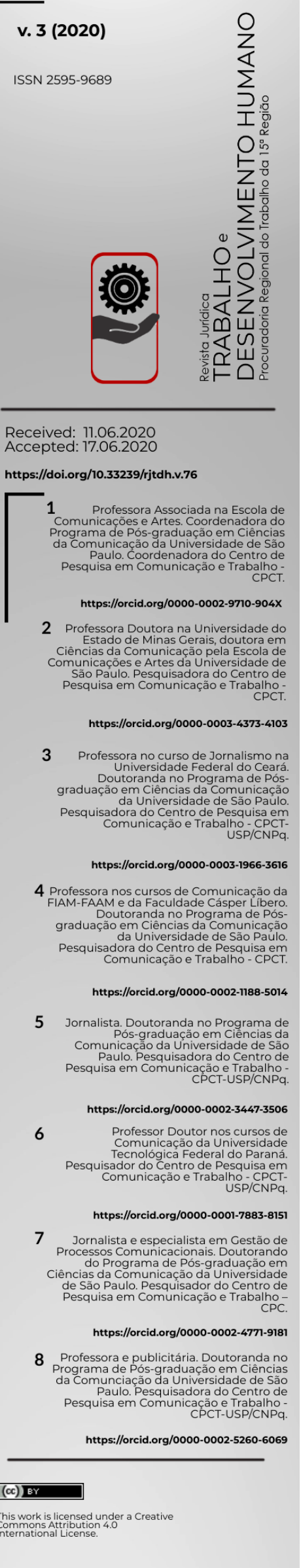

\title{
Como trabalham os comunicadores na pandemia da Covid-19?
}

How communicators work in pandemic Covid-19?

¿Como trabajan los comunicadores en la pandemia de Covid-19?

Roseli Figaro'

Janaina Visibeli Barros ${ }^{2}$

Naiana Rodrigues da Silva ${ }^{3}$

Camila Acosta Camargo ${ }^{4}$

Ana Flávia Marques da Silva ${ }^{5}$

João Augusto Moliani ${ }^{6}$

Jamir Osvaldo Kinoshita ${ }^{7}$

Daniela Ferreira de Oliveira ${ }^{8}$

\begin{abstract}
RESUMO
Este artigo trata dos resultados da pesquisa: Como trabalham os comunicadores na pandemia da Covid-19? A investigação não probabilística, de carácter exploratório, aplicou questionário com questões abertas e fechadas, online, via plataforma do Google, no período de 5 a 30 de abril, e ficou disponível nas redes sociais do Centro de Pesquisa em Comunicação e Trabalho e de parceiros da pesquisa. O questionário obteve 557 respondentes comunicadores de todo o país, em diferentes atividades laborais. Os resultados, discutidos neste artigo, mostram que há aumento das jornadas de trabalho, há intensificação da atividade laboral, com uso de equipamentos próprios, cujos custos oneram o comunicador; intensificou-se o uso das plataformas e aplicativos no processo produtivo, para a organização, controle da gestão do trabalho, da rotina produtiva e, sobretudo, do fluxo de informação. As empresas, em geral, adotaram o home office e, quando a atividade não permite o distanciamento, criaram turnos mistos, presencial e a distância, nesses casos, a adoção de EPIs se apresenta como um complicador da relação trabalhador-empresa-público. No home office, os comunicadores precisam reorganizar o espaço doméstico e o acompanhamento dos filhos. Os profissionais se sentem mais cansados, inseguros com o futuro, temem o contágio, pela vida dos familiares, a situação de colapso do sistema de saúde, mas preocupam-se com o trabalho: perder o emprego, ter redução de salário, perder contratos etc. são preocupações que atormentam e tornam as jornadas mais estressantes. Mesmo com todos esses problemas, há um grande engajamento para a realização do trabalho.
\end{abstract}

PALAVRAS-CHAVE: comunicadores. mundo do trabalho. Covid-19. trabalho em home office.

\section{ABSTRACT}

This article deals with the results of the research: How do communicators work in the Covid-19 pandemic? The non-probabilistic investigation, of an exploratory nature, applied a questionnaire with open and closed questions, online, via the Google platform, in the period from 5 to $30 \mathrm{April}$, and was available on social networks of Communication and Work Research Center and research partners. The questionnaire obtained 557 respondent communicators from all over the country, in different work activities. The results, discussed in this article, show that, there is an increase in working hours, there is an intensification of work activity, with the use of own equipment, whose costs burden the communicator; the use of platforms and applications in the production process was intensified for the organization, control of work management, production routine and, above all, information flow. Companies, in general, adopted the home office and, when the activity does not allow distance, created mixed shifts, in person and at a distance, in these cases, the adoption of PPE presents itself as a complicator of the worker-companypublic relationship. In the home office, communicators need to reorganize the domestic space and monitor their children. Professionals feel more tired, insecure about the 
Revista Jurídica Trabalho e Desenvolvimento Humano Procuradoria Regional do Trabalho da 15a Região

future, fear contagion, for the lives of family members, the situation of collapse of the health system, but are concerned with work: losing their jobs, having a salary reduction, losing contracts etc. they are worries that torment and make workday more stressful. Even with all these problems, there is a great commitment to get the job done.

KEYWORDS: communicators. world of work. Covid-19. work at home office.

\section{RESUMEN}

Este artículo aborda los resultados de la investigación: ¿Cómo trabajan los comunicadores en la pandemia de Covid-19? La investigación no probabilística, de carácter exploratorio, aplicó un cuestionario con preguntas abiertas y cerradas, en línea, a través de la plataforma Google, en el período del 5 al 30 de abril, y estuvo disponible en las redes sociales del Centro de Investigaciones en Comunicación y Trabajo y de los parceros de la investigación. El cuestionario obtuvo 557 comunicadores encuestados de todo el país, en diferentes actividades laborales. Los resultados, discutidos en este artículo, muestran que, hay un aumento en las horas de trabajo, hay una intensificación de la actividad laboral, con el uso de equipos propios, cuyos costos son una carga para el comunicador; el uso de plataformas y aplicaciones en el proceso de producción se intensificó para la organización, el control de la gestión del trabajo, la rutina de producción y, sobre todo, el flujo de información. Las empresas, en general, adoptaron el home office y, cuando la actividad no permite la distancia, crearon turnos mixtos, en persona y a distancia, en estos casos, la adopción de EPP compromete la relación trabajador-empresa-público. En el home office, los comunicadores deben reorganizar el espacio doméstico y acompañar a sus hijos. Los profesionales se sienten más cansados, inseguros sobre el futuro, temen el contagio, por la vida de los miembros de la familia, la situación de colapso del sistema de salud, pero están preocupados por el trabajo: perder sus trabajos, tener una reducción salarial, perder contratos, etc. son preocupaciones que atormentan y hacen que la jornada laboral sea más estresante. Incluso con todos estos problemas, existe un gran compromiso para hacer el trabajo.

PALAVRAS-CLAVE: comunicadores, mundo del trabajo, Covid-19, trabajo en home office.

INTRODUÇÃO

Esta pesquisa foi motivada pelo fato de já em março de 2020, no início de pandemia Covid-19, no Brasil, haver notícias sobre as difíceis condições de trabalho vivenciadas pelos comunicadores. Com a investigação em andamento, tivemos, no dia 14 de abril, a notícia da morte do jornalista José Augusto do Nascimento Silva ${ }^{1}$, empregado do SBT. Além dele, outras vidas foram ceifadas depois². Esses fatos lastimáveis exigiam sabermos sobre as condições de trabalho dos comunicadores.

\footnotetext{
1 PERLINE, Gabriel. Antes de morrer por coronavírus, jornalista do SBT acusou emissora de negligência. Publicado pelo UOL em 13 abril de 2020. Disponível em: $<$ https://noticiasdatv.uol.com.br/mobile/noticia/televisao/antes-de-morrer-por-coronavirus-jornalistado-sbt-acusou-emissora-de-negligencia-35657>. Acesso em: 25 jun. 2020.

${ }^{2}$ Ver notícias disponíveis em: PITOMBO, João Pedro. Jornalista de afiliada da Globo no Maranhão morre. Publicado pela Folha de São Paulo em 22 de abril 2020. Disponível em: <https://www1.folha.uol.com.br/cotidiano/2020/04/jornalista-de-afiliada-da-globo-no-maranhaomorre-de-covid-19.shtml>. Acesso em: 25 jun 2020; G1 RN. Jornalista de 74 anos morre com coronavírus em Mossoró. Publicado pelo G1 em 02 maio de 2020. Disponível em: <https://g1.globo.com/rn/rio-
} 
Revista Jurídica Trabalho e Desenvolvimento Humano Procuradoria Regional do Trabalho da 15a Região

O afastamento social e o home office foram indicados como ações necessárias para diminuir o impacto da infecção pelo novo coronavírus. No entanto, nem todos os profissionais da comunicação podem manter o distanciamento social. No exercício profissional, o serviço público da informação, exige, muitas vezes, a apuração do fato in loco. Também se cobra a pesquisa para a produção da informação qualificada sobre o produto e a verificação dos dados para traçar políticas de comunicação para as instituições. Na divulgação científica, no setor de saúde, seja nos órgãos públicos ou privados, hospitais, ministério, secretarias ou no apoio institucional, os profissionais da comunicação estão atentos, atuantes, presentes.

Para além da pandemia da Covid-19, os profissionais da comunicação têm enfrentado profundas mudanças no mundo do trabalho. A base sociotécnica dos meios de produção se transformou com os meios digitais e a internet. Esses eventos foram assimilados pelo mercado da comunicação ampliando-se a precarização do trabalho, a densificação do ritmo da atividade e o aumento das horas trabalhadas. Ao contrário do que se imaginou, no final do século $X X$, as maravilhas da comunicação digital e da internet causaram, pela forma da apropriação privada de seus lucros, transtornos para a classe-que-vive-do-trabalho ${ }^{3}$. Empresas de notícia, agências de comunicação e de publicidade e assessorias de comunicação transformaram-se no tocante à estrutura da planta empresarial e organizacional ${ }^{4}$ e com isso as demissões e os contratos precários aumentaram consideravelmente. Também a maneira de monetização da informação passou por mudanças. A verba publicitária para a internet tem valorizado as formas de atuação de plataformas como Google, Facebook, Amazon entre outras, fazendo com

grande-do-norte/noticia/2020/05/02/jornalista-de-74-anos-morre-com-covid-19-em-mossoro.ghtml>. Acesso em: 25 jun. 2020; G1 Rio. Jesus Chediak morre de Covid-19 no Rio de Janeiro. Publicado pelo G1 em 08 de maio de 2020. Disponível em: <https://g1.globo.com/rj/rio-dejaneiro/noticia/2020/05/08/jesus-chediak-morre-de-covid-19-no-rio-de-janeiro.ghtml>. Acesso em: 25 jun. 2020.

${ }^{3}$ ANTUNES, Ricardo. 0 privilégio da servidão: O novo proletariado de serviços na era digital. São Paulo: Boitempo, 2018.

${ }^{4}$ FIGARO, Roseli; NONATO, Cláudio; GROHMANN, Rafael (Org.). As mudanças no mundo do trabalho dos jornalistas. São Paulo: Salta, 2013; FIGARO, Roseli (org.). As relações de comunicação e as condições de produção no trabalho de jornalistas em arranjos econômicos alternativos às corporações de mídias. São Paulo: ECA-USP, 2018.

FIGARO, Roseli; BARROS, Janaina V.; SILVA, Naiana R.; CAMARGO, Camila A.; SILVA, Ana Flávia M.; MOLIANI, João Augusto; OLIVEIRA, Daniela Ferreira de. Como trabalham os comunicadores na pandemia da Covid-19? Revista Jurídica Trabalho e Desenvolvimento Humano, Campinas, EDIÇÃO ESPECIAL - DOSSIÊ COVID-19, p. 1-39, 2020. 
Revista Jurídica Trabalho e Desenvolvimento Humano Procuradoria Regional do Trabalho da 15a Região

que as empresas tradicionais de mídia se tornem dependentes da lógica da visibilidade e da circulação, configuradas por esses conglomerados de plataformas.

Assim, a pandemia da Covid-19 encontra o setor da comunicação em profunda crise, com um quadro bastante dramático para o mundo do trabalho dos comunicadores: demissões, contratos precários, rebaixamento salarial, densificação do trabalho, todo tipo de estresse além do quadro de incertezas sobre o futuro.

Nesse cenário de crise pandêmica e de crise pelas transformações no mundo do trabalho, o objetivo da pesquisa é identificar as condições de trabalho dos comunicadores no desempenho de suas funções durante a pandemia da Covid-19. Buscamos saber em quais condições trabalham os profissionais da comunicação durante a pandemia, como estão se cuidando, quais meios de trabalho utilizam, como se dá a atividade exercida via home office, quantas horas trabalham e quais as principais aflições e os desafios para realizar o trabalho no quadro de pandemia.

\section{METODOLOGIA}

A pesquisa foi realizada por meio de um questionário com perguntas de múltipla escolha e com questões abertas para respostas discursivas, no formulário da plataforma Google. O questionário contou com perguntas relativas à autorização dos respondentes para a divulgação dos dados, bem como declaração de interesse em participar da continuidade dessa investigação. As perguntas abordaram perfil dos respondentes (nome, idade, estado civil, filhos, local de moradia, escolaridade); dados profissionais (profissão, cargo/função, empresa, vínculo contratual); condições do exercício profissional (tipo de veículo/linguagens do trabalho, equipamentos, principais atividades, carga horária); condições de trabalho na pandemia (carga horária, providências da empresa, organização da rotina de trabalho, como está se sentindo, principais medos e depoimento).

A amostra não-probabilística foi construída a partir dos respondentes voluntários que tiveram acesso ao formulário por meio do site e das redes sociais do

FIGARO, Roseli; BARROS, Janaina V.; SILVA, Naiana R.; CAMARGO, Camila A.; SILVA, Ana Flávia M.; MOLIANI, João Augusto; OLIVEIRA, Daniela Ferreira de. Como trabalham os comunicadores na pandemia da Covid-19? Revista Jurídica Trabalho e Desenvolvimento Humano, Campinas, EDIÇÃO ESPECIAL - DOSSIÊ COVID-19, p. 1-39, 2020. 
Revista Jurídica Trabalho e Desenvolvimento Humano Procuradoria Regional do Trabalho da 15a Região

Centro de Pesquisa em Comunicação e Trabalho - CPCT e das redes sociais das instituições ${ }^{5}$ que apoiaram a pesquisa. No período de 5 a 30 de abril de 2020, em que o questionário esteve aberto ao acesso dos comunicadores, obteve-se 557 respondentes.

Das informações obtidas a partir do formulário da plataforma Google foi feita a transferência dos dados para uma planilha no programa Excel. Essa planilha teve tratamento categorial para padronização da grafia das respostas fechadas. As perguntas abertas tiveram as respostas organizadas em termos de proximidade de campos de sentidos e foram criadas nuvens de palavras das respostas abertas dos participantes. A partir dessas estratégias, foram formuladas categorias que nos permitem fazer afirmações sobre os respondentes.

\section{CONTEXTO DOS RESPONDENTES}

Os resultados foram organizados em quadros, gráficos e sentenças analíticas que possibilitam perceber as condições em que trabalham os comunicadores nesse período de pandemia. Em termos gerais, podemos afirmar que a maioria trabalha em home office em condições desconfortáveis para a família e utilizando toda a infraestrutura própria em termos de equipamentos, suporte de energia elétrica, conexão com internet, uso de softwares e aplicativos necessários para sua atividade. O trabalho, para a maioria, se intensificou e a organização da rotina laboral ocupou todo o espaço e o tempo da/na

\footnotetext{
${ }^{5}$ Associação Brasileira de Agências de Comunicação (Abracom); Associação Brasileira de Imprensa (ABI); Associação Brasileira de Pesquisadores de Comunicação; Associação Brasileira de Jornalismo Investigativo (Abraji); Associação Brasileira de Pesquisadores em Jornalismo (SBPJor); Associação Brasileira de Pesquisadores em Comunicação Organizacional e Relações Públicas (Abrapcorp); Conselho Regional de Relações Públicas da 2a Região (Conrerp SP/PR); Sociedade Brasileira de Estudos Interdisciplinares da Comunicação (Intercom); Federação Nacional dos Jornalistas (Fenaj); Sindicato dos Jornalistas Profissionais no Estado de São Paulo; Sindicato dos Jornalistas Profissionais no Estado do Ceará (Sindijorce); Sindicato dos Jornalistas Profissionais do Paraná; Sindicato dos Jornalistas Profissionais de Minas Gerais;Sindicato dos Jornalistas Profissionais do Distrito Federal (SJPDF); Sindicato dos Jornalistas Profissionais do Rio Grande do Sul; Blogs e portais de notícias gerais e especializados, como os portais Imprensa, Jornalistas \& Cia. e Jornal da USP. Prefeituras de São Paulo e de Guarulhos, SP.
}

FIGARO, Roseli; BARROS, Janaina V.; SILVA, Naiana R.; CAMARGO, Camila A.; SILVA, Ana Flávia M.; MOLIANI, João Augusto; OLIVEIRA, Daniela Ferreira de. Como trabalham os comunicadores na pandemia da Covid-19? Revista Jurídica Trabalho e Desenvolvimento Humano, Campinas, EDIÇÃO ESPECIAL - DOSSIÊ COVID-19, p. 1-39, 2020. 
casa. Para a maioria, trabalham-se mais horas, em ritmo mais intenso, em um quadro de incertezas sobre as condições de salário e emprego, conforme passamos a relatar.

Conforme o Gráfico 1, pode-se verificar a abrangência dos participantes. São Paulo obteve 206 participantes, coerente com a maior concentração desse perfil profissional no país, bem como com a tradição de pesquisas do CPCT. Minas Gerais, com 58 respondentes; Rio Grande do Sul, com 51; Ceará, com 38 respondentes; e Paraná, com 29 participantes da pesquisa, revelam também a extensão das atividades de pesquisa do CPCT bem como a presença profissional dos comunicadores. $O$ estado do Rio de Janeiro, com 21 respondentes, tem o número expressivo de trabalhadores da comunicação, embora não tenhamos obtido maior participação. Em Portugal, tivemos um respondente. É importante destacar que a pesquisa não tem finalidade de representação de amostra quantitativa e estatística. Pois, trata-se de um estudo qualitativo, não-probabilístico, cujo objetivo é identificar, de maneira exploratória, os elementos que compõem o quadro de enfrentamento que os profissionais têm articulado para manterem-se em atividade de trabalho durante a pandemia da Covid19.

\section{Gráfico 1 - Local}

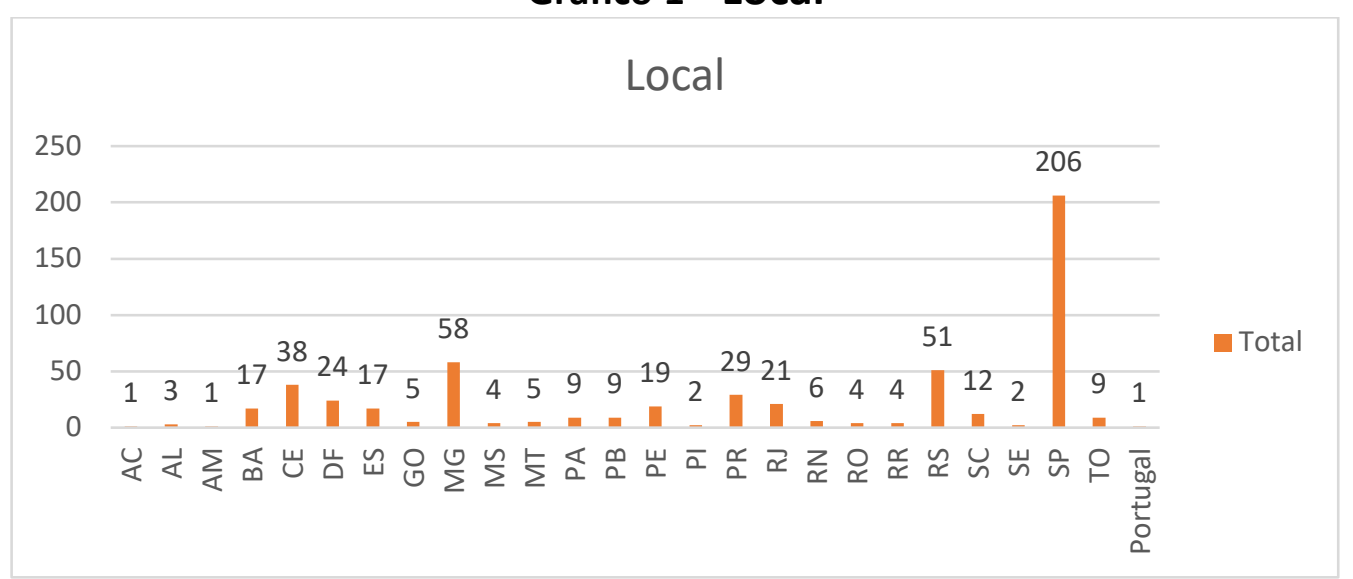

Fonte: Pesquisa CPCT/Como trabalham os comunicadores na pandemia da Covid-19? 
Revista Jurídica Trabalho e Desenvolvimento Humano Procuradoria Regional do Trabalho da 15a Região

\section{ESCOLARIDADE, FORMAÇÃO PROFISSIONAL E PROFISSÃO}

O questionário buscou conhecer o perfil dos respondentes em relação à escolaridade, formação profissional e profissão. A maioria absoluta dos respondentes tem graduação completa. Número inexpressivo (2\%) declarou ter ensino médio ou formação superior incompleta. Entre esses estão os estudantes que no momento cursam a graduação e fazem estágio. Conforme mostra o Gráfico 2, há formação pósgraduada - mestrado e doutorado - entre mais de $20 \%$ dos respondentes.

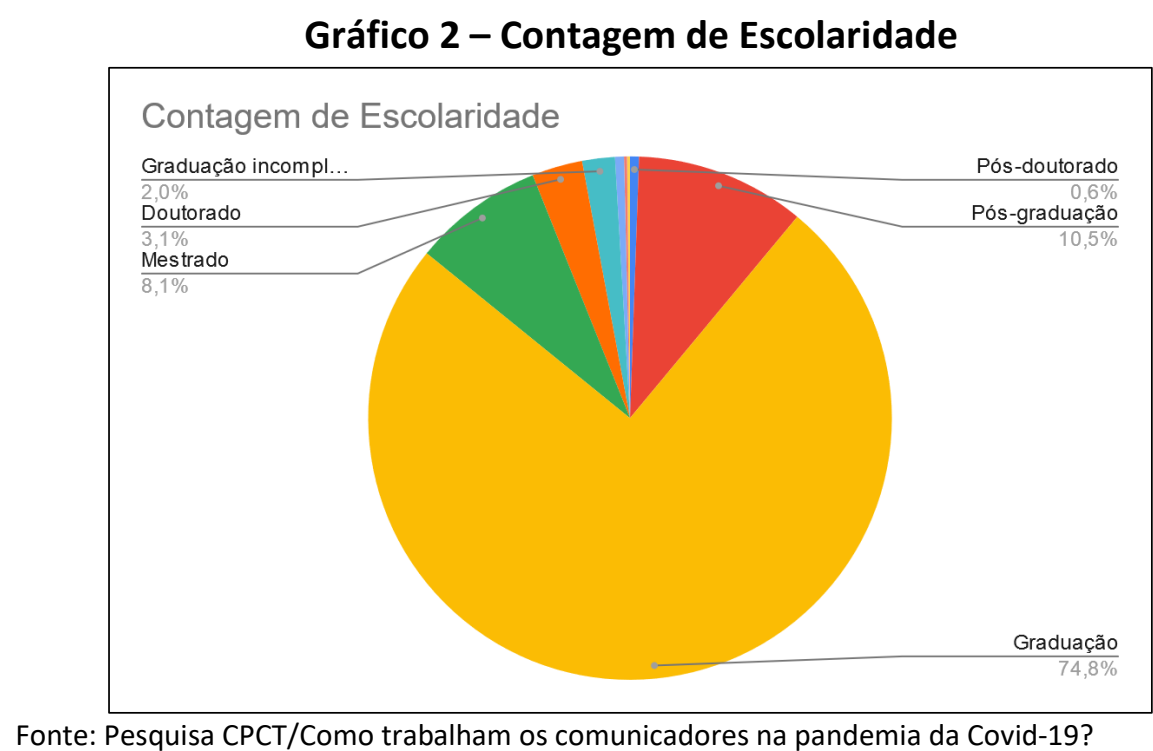

A formação profissional, para 74,5\% dos respondentes, conforme mostra o Gráfico 3, deu-se em cursos de bacharelado em Jornalismo (Comunicação Social - Jornalismo). Os demais também se formaram nas áreas de Comunicação em Relações Públicas, Radialismo, Publicidade e Propaganda. Há respondentes com duas graduações: Jornalismo e História; Jornalismo e Letras são cursos declarados; e há declaração de formados em outras áreas: Psicologia, Direito, Administração, Engenharia e Marketing, ao quais, em seus percursos profissionais, buscaram especializações, pós-graduação para adentrarem na área da Comunicação. Os pós-graduados, com mestrado e 
Revista Jurídica Trabalho e Desenvolvimento Humano Procuradoria Regional do Trabalho da 15a Região

doutorado e mesmo pós-doutorado, dedicam-se à vida universitária ao ensino e à pesquisa.

Gráfico 3 - Formação Profissional

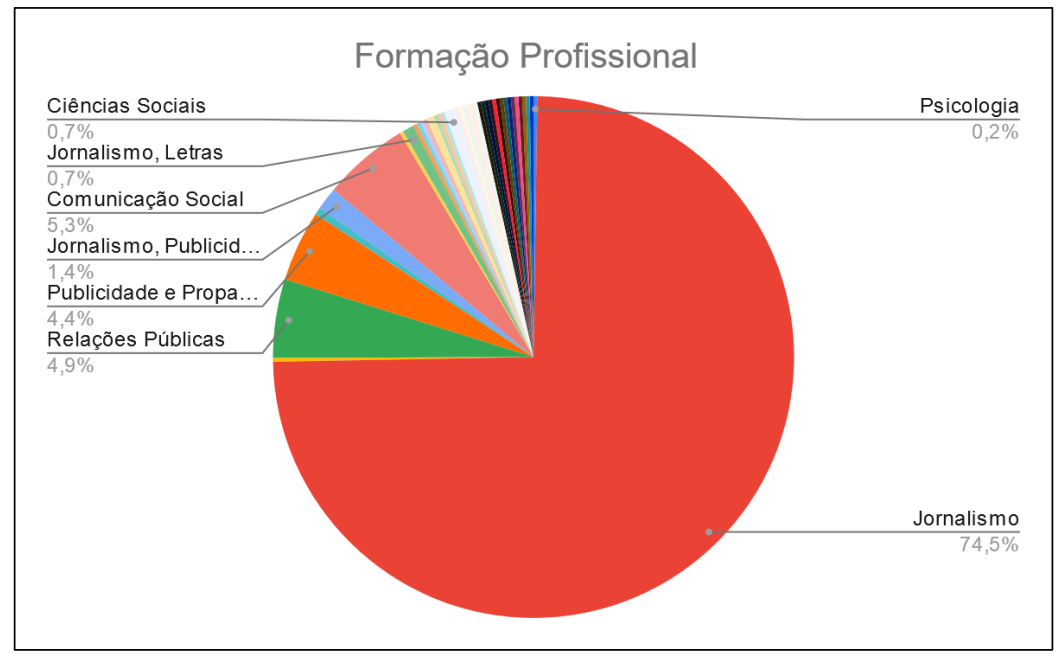

Fonte: Pesquisa CPCT/Como trabalham os comunicadores na pandemia da Covid-19?

Sobre a profissão, o Gráfico 4 mostra que $61,2 \%$ dos respondentes da pesquisa afirmam trabalhar como jornalistas. Esse dado, sobretudo quando se verificam as informações sobre formação acadêmica, mostra a amplitude de papéis profissionais que esses respondentes desempenham a partir da sua formação. Há um número expressivo de comunicadores publicitários, relações públicas e professores (5\%). Estes últimos vêm de uma formação em comunicação e são profissionais do ensino e da pesquisa na área da Comunicação, seja na graduação seja na pós-graduação. É interessante destacar que 5,6\% dos respondentes afirmaram ser repórteres e há mesmo aqueles que se declaram jornalistas e professores, jornalista e servidor público, jornalista e empresário. Há entre os respondentes também aqueles que se declararam assessores de comunicação ou assessores de imprensa. Essa multiplicidade de profissões declaradas será mais bem compreendida ao verificarmos como esses respondentes nomeiam a atividade que atualmente desenvolvem.

FIGARO, Roseli; BARROS, Janaina V.; SILVA, Naiana R.; CAMARGO, Camila A.; SILVA, Ana Flávia M.; MOLIANI, João Augusto; OLIVEIRA, Daniela Ferreira de. Como trabalham os comunicadores na pandemia da Covid-19? Revista Jurídica Trabalho e Desenvolvimento Humano, Campinas, EDIÇÃO ESPECIAL - DOSSIÊ COVID-19, p. 1-39, 2020. 
Revista Jurídica Trabalho e Desenvolvimento Humano Procuradoria Regional do Trabalho da 15a Região

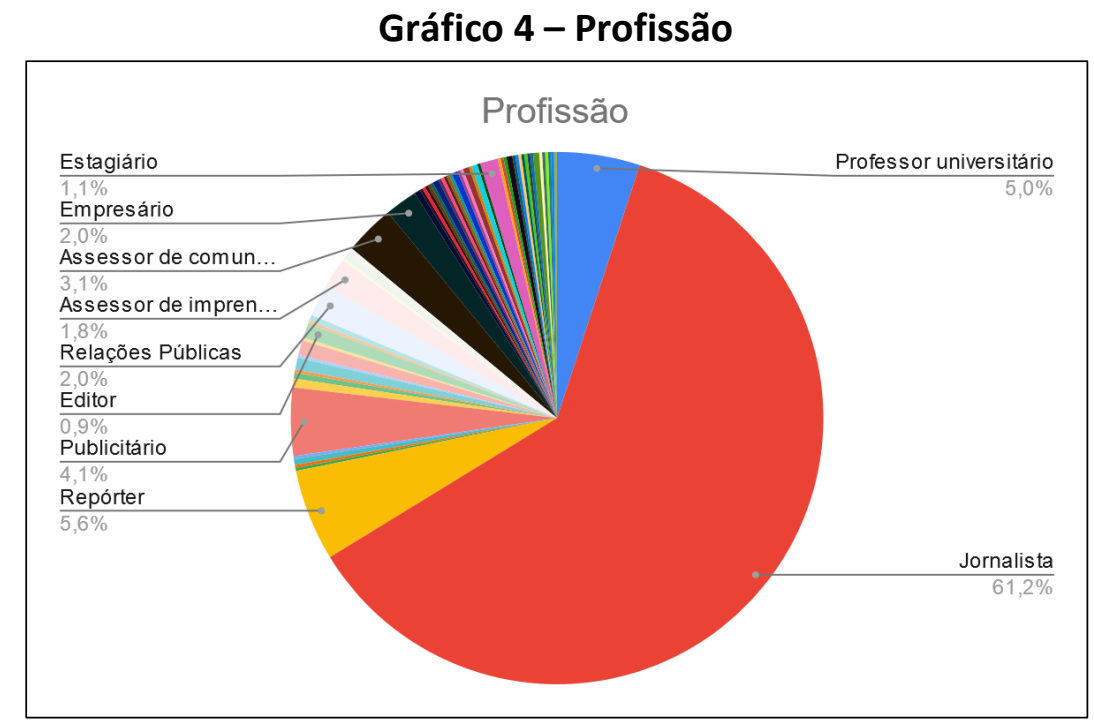

Fonte: Pesquisa CPCT/Como trabalham os comunicadores na pandemia da Covid-19?

\section{AS PRINCIPAIS ATIVIDADES QUE REALIZAM}

Quando os respondentes declaram as atividades que desempenham na atualidade, vê-se a multiplicidade de funções e responsabilidades e como elas vão muito além do quadro tradicional descritivo para a formação em Comunicação, seja em Jornalismo, Publicidade e Propaganda ou Relações Públicas.

Nas declarações já se apresentam a prática da escrita para a internet, sites e blogs, o que configura a escrita hipertextual, com múltiplas linguagens e atividade em multiplataformas. Também há o jornalista que se declara como tal e produz releases, fotos, vídeos e faz contato com repórteres. Essas são típicas funções de assessoria de comunicação ou assessoria de imprensa. Eles também trabalham com uma escrita multiplataforma, linguagens diversas (escrita, audiovisual, fotográfica) e o gerenciamento de contatos para que o discurso produzido alcance os canais da grande mídia.

A tipologia de declaração repete-se em grande parte dos respondentes, ora aprofundando-se as atividades identificadas como de assessoria de comunicação marcas, clientes, políticos - ora intensificando-se o perfil jornalístico da reportagem, da cobertura in loco, sobretudo dos profissionais de televisão. Pode-se dizer que o perfil 
Revista Jurídica Trabalho e Desenvolvimento Humano Procuradoria Regional do Trabalho da 15a Região

mais estabilizado de atividades se dá entre os professores, muito embora as nomenclaturas: ensino, pesquisa e extensão acobertem uma gama de funções que vão do didático-pedagógico ao editor de revistas científicas, do gestor institucional ao prospector de novas áreas e recursos e ao acompanhamento do desenvolvimento profissional de estagiários, entre outras.

A profissão de publicitário é uma das que mais se alterou no período recente com a internet 2.0 e as redes sociais. Uma nova gama de linguagens e de midiuns surgiram diversificando as possibilidades de atuação de empresas, produtos e instituições. Além disso, a globalização levou ao desaparecimento do modelo de negócio das antigas agências de publicidade ${ }^{6}$, tornando-as braços de grandes conglomerados internacionais da área. Com o advento da publicidade programática, ou seja, aquela vinculada aos perfis dos internautas em sites e redes sociais captadas pelo Google, Facebook etc., as receitas e o modelo do negócio da publicidade também se transformaram profundamente, mais ainda os perfis desses profissionais.

Uma amostra das declarações dos profissionais de Relações Públicas que participaram da pesquisa, sobre profissão, cargo e atividade, também revela uma profissão cujo leque de atividades se mantém mais estabilizado. Apesar das novas mídias e do digital, os profissionais atuam em atendimento, gerenciamento de contas, comunicação organizacional, assessoria a eventos, planejamento institucional entre outras atividades. O marketing digital apareceu como novidade nos anos 2000.

Por outro lado, a profissão de jornalista, além das transformações no mundo do trabalho que já discutimos em inúmeras pesquisas e publicações ${ }^{7}$, tem peculiaridades que precisam ser mais bem estudadas. As declarações nos mostraram profissionais nomeando-se jornalistas e exercendo cargos, cujas atividades estão distantes daquelas

\footnotetext{
6 CASAQUI, Vander; LIMA, Manolita Correia; RIEGEL, Viviane (Org.). Trabalho em publicidade e propaganda. São Paulo: Atlas, 2011.

7 LIMA, Cláudia do C. Nonato. Jornalistas, blogueiros, migrantes da comunicação: em busca de novos arranjos econômicos para o trabalho jornalístico com maior autonomia e liberdade de expressão. Tese de doutorado. Pós-graduação em Ciências da Comunicação, ECA-USP, 2015. Disponível em: https://www.teses.usp.br/teses/disponiveis/27/27152/tde-26062015-112522/pt-br.php; FIGARO, Roseli; NONATO, Cláudio; GROHMANN, Rafael (Org.). As mudanças no mundo do trabalho dos jornalistas. São Paulo: Salta, 2013.
}

FIGARO, Roseli; BARROS, Janaina V.; SILVA, Naiana R.; CAMARGO, Camila A.; SILVA, Ana Flávia M.; MOLIANI, João Augusto; OLIVEIRA, Daniela Ferreira de. Como trabalham os comunicadores na pandemia da Covid-19? Revista Jurídica Trabalho e Desenvolvimento Humano, Campinas, EDIÇÃO ESPECIAL - DOSSIÊ COVID-19, p. 1-39, 2020. 
tradicionais pensadas e teorizadas como jornalismo. Esses profissionais executam tarefas de marketing, assessoria de comunicação, administração, mas continuam se identificando com a profissão de jornalista.

Certamente, as habilidades e competências pessoais no âmbito do desenvolvimento da formação superior, bem como da experiência, carregam as histórias profissionais para deslocamentos nem sempre planejados. Também as circunstâncias das mudanças no parâmetro dos meios de produção na área da comunicação e a profunda crise do setor ajudam a explicar esses deslizamentos entre formação, profissão e exercício profissional. No entanto, chama atenção que são os jornalistas aqueles que, segundo nossas pesquisas, mais têm transitado para funções cujo resultado não é o jornalismo. A tese de doutorado de João Augusto Moliani ${ }^{8}$ faz estudo minucioso sobre as atividades de trabalho dos assessores de imprensa/comunicação. Aqui apenas apontamos esses temas, que merecem aprofundamento em oportunidade mais adequada.

\section{PERFIL - FAIXA ETÁRIA, GÊNERO, ESTADO CIVIL E FILHOS}

Quase a metade dos respondentes estão na faixa etária de 30 a 39 anos. Temos apenas 1 respondente com 19 anos, estagiário, estudante de jornalismo. Na faixa de 20 a 29 anos, o número de respondentes também é grande, 120. Ou seja, dos 19 aos 39 anos temos mais de $60 \%$ dos respondentes. Chama atenção, no entanto, que diferente de outras pesquisas que já realizamos, os respondentes das faixas de 50 a 69 anos - 101 participantes - mostraram-se bastante engajados em responder sobre seu trabalho.

Entre os respondentes, identificamos 334 nomes femininos e 223 nomes masculinos. Dado que se mostra coerente com a identidade de gênero que os profissionais da área da comunicação vêm apresentando nas pesquisas desde a primeira

\footnotetext{
${ }^{8}$ MOLIANI, J. A. O trabalho em agências de comunicação: processos produtivos e densificação da atividade no jornalismo de rabo preso com o cliente. Tese de doutorado. Programa de Pós-graduação em Ciências da Comunicação. Universidade de São Paulo, 2020.
}

FIGARO, Roseli; BARROS, Janaina V.; SILVA, Naiana R.; CAMARGO, Camila A.; SILVA, Ana Flávia M.; MOLIANI, João Augusto; OLIVEIRA, Daniela Ferreira de. Como trabalham os comunicadores na pandemia da Covid-19? Revista Jurídica Trabalho e Desenvolvimento Humano, Campinas, EDIÇÃO ESPECIAL - DOSSIÊ COVID-19, p. 1-39, 2020. 
década dos anos 2000. A feminização da profissão tem sido estudada por diferentes abordagens, sobretudo aquelas que problematizam as questões do assédio e da violência sexual no trabalho, a diferença salarial entre os sexos, as jornadas estendidas com as tarefas da casa e com os filhos. Este último aspecto, as duplas e triplas jornadas, entre as mulheres comunicadoras também aparece nos relatos dos respondentes desta pesquisa e será discutido mais adiante.

A maioria dos respondentes se declara solteiro em relação ao estado civil. No entanto, quando agregamos os dados dos declarantes casados e dos declarantes que mantém união estável, observamos que os números se equiparam.

Dentre os respondentes, 43,9\% têm filhos. Dado importante quando se avaliam as condições de trabalho, vínculos empregatícios e níveis salariais ${ }^{9}$ das categorias da área da Comunicação. A questão da organização da família com filhos demanda custos maiores e tempo para acompanhar a formação e educação dos filhos. Os profissionais da área da comunicação, sobretudo jornalistas e publicitários, têm longas jornadas de trabalho, bem como rotinas bastante estressantes e precisam ser consideradas ainda mais em situação de afastamento social. Há vários relatos de mães e de pais que estão encontrando maior dificuldade nas atividades em home office, devido à necessidade de ocuparem-se também com os afazeres vinculados às crianças.

\section{ONDE TRABALHAM E CONDIÇÕES DE TRABALHO}

O questionário da pesquisa aborda o respondente sobre onde trabalha, o nome da empresa, jornada de trabalho, ritmo e intensidade do trabalho, providencias tomadas em relação à pandemia entre outras questões a serem aqui tratadas. No

\footnotetext{
${ }^{9}$ Nossa pesquisa não perguntou sobre nível salarial dos respondentes, mas vale destacar os pisos salariais das categorias de Jornalista (Fenaj disponibiliza os valores em: https://fenaj.org.br/sindicatos/convencoes-e-acordos-coletivos/pisos-salariais-atuais/), Relações Públicas (o site https://www.salario.com.br/profissao/relacoes-publicas-a-cbo-142325/ dá a média salarial da profissão no Brasil) e dos publicitários (o site do sindicato de São Paulo disponibiliza os valores http://www.sindicatopublicitariossp.com.br/web/pisos-salariais).
}

FIGARO, Roseli; BARROS, Janaina V.; SILVA, Naiana R.; CAMARGO, Camila A.; SILVA, Ana Flávia M.; MOLIANI, João Augusto; OLIVEIRA, Daniela Ferreira de. Como trabalham os comunicadores na pandemia da Covid-19? Revista Jurídica Trabalho e Desenvolvimento Humano, Campinas, EDIÇÃO ESPECIAL - DOSSIÊ COVID-19, p. 1-39, 2020. 
tocante ao local de trabalho, pode-se identificar 12 categorias de respostas, conforme ilustra e informa o Quadro 1.

\section{Quadro 1-Onde trabalham os comunicadores}

\begin{tabular}{|l|c|}
\hline Agência de Comunicação, Marketing e Publicidade & $\mathbf{8 5}$ \\
\hline Assessoria de comunicação & 114 \\
\hline Empresa privada & 16 \\
\hline Organizações não governamentais & 23 \\
\hline Serviço público & 16 \\
\hline Mídia tradicional, Serviço público & $\mathbf{1}$ \\
\hline Mídia tradicional & 167 \\
\hline Mídia alternativa/independente/comunitária/sindical & 55 \\
\hline Instituição de ensino, pesquisa e extensão & 68 \\
\hline Inst. de ensino, pesq. e extensão, Ag. de Comunic., Mkt e Publicidade & $\mathbf{1}$ \\
\hline Editora & $\mathbf{2}$ \\
\hline Autônomo & $\mathbf{8}$ \\
\hline
\end{tabular}

Fonte: Pesquisa CPCT/Como trabalham os comunicadores na pandemia da Covid-19?

Entre os respondentes do questionário, 167 declararam-se trabalhar em mídia tradicional; seguidos por 114 que declararam trabalhar em assessoria de comunicação. Três outras declarações de respondentes em relação a local de trabalho mostram números expressivos: 85 trabalham em agência de comunicação, marketing e publicidade; 68 trabalham em instituições de ensino, pesquisa e extensão; e 55 trabalham em mídia alternativa/independente/comunitária/sindical. Desse modo, a abrangência de perfis de organizações e de atividades é bastante satisfatória para dar ideia da realidade de onde trabalham os comunicadores.

\section{SUPORTE TÉCNICO COM O QUAL TRABALHAM}

É importante destacar os suportes técnicos ou as ambiências com os quais trabalham os comunicadores. Há uma miríade de declarações por tipo de associação que fazem os profissionais ao utilizarem suportes do impresso, do áudio, do vídeo, da internet e suas combinações possíveis. Destacamos as mais numerosas e a internet é a ambiência em que 33,9\% dos respondentes declaram trabalhar. Essa ambiência 
comporta inúmeras linguagens e combina veículos como sites, grupos de WhatsApp, Facebook, Twitter, Instagram, dentre outros. A combinação de impresso e internet corresponde a $11 \%$ das respostas; em televisão trabalham 7,5\% dos respondentes. Há respondentes que trabalham com rádio $(3,8 \%)$; há os que trabalham somente com impresso (4,1\%); impresso, rádio e TV, 4,3\% dos respondentes; rádio e internet, 2,3\% dos respondentes. O leque de combinações é variado e chama atenção os respondentes professores que declaram a ambiência de sala de aula $(2,9 \%)$ como o suporte para seu trabalho, conforme mostra o Gráfico 5.

\section{Gráfico 5-Com qual suporte trabalha?}

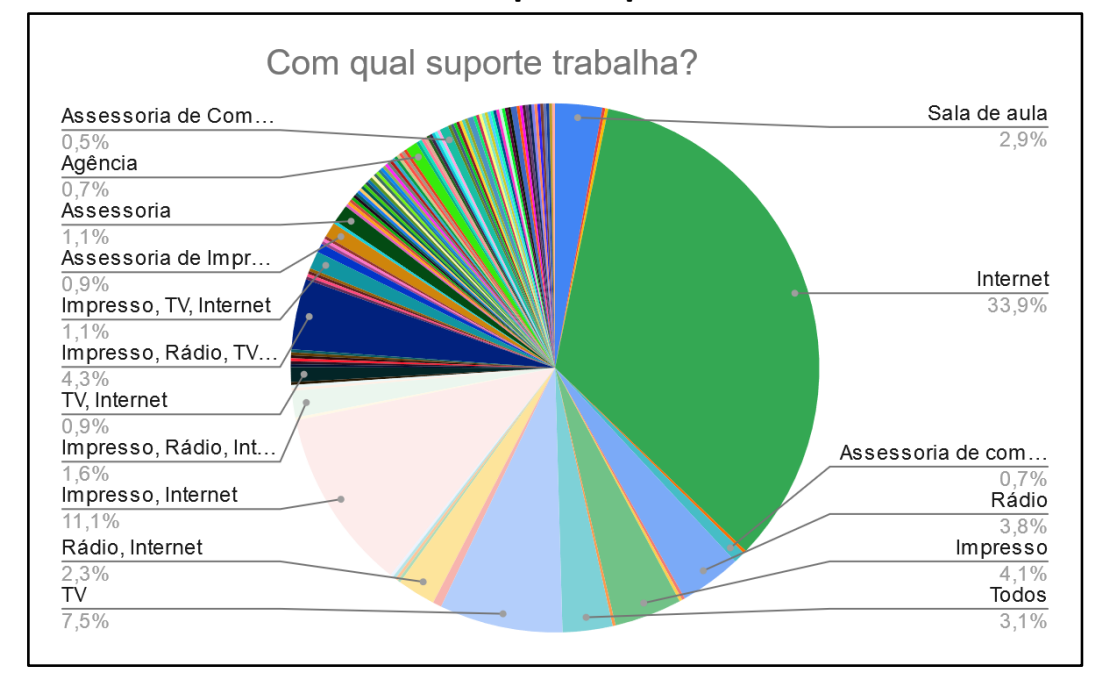

Fonte: Pesquisa CPCT/Como trabalham os comunicadores na pandemia da Covid-19?

\section{AS MUDANÇAS NA ROTINA DO TRABALHO COM A COVID-19}

Selecionamos, aleatoriamente, alguns enunciados declarados para a questão: 0 que mudou em sua rotina de trabalho com a covid-19? Há respostas como a da redatora de um blog: "Na prática, nada. Já fazia home office"; e a da repórter: "Passei a fazer home office por ter um filho pequeno." Entre as inúmeras contribuições dos respondentes, existem relatos sobre o novo momento de reorientação das ações, aprendizado de novas ferramentas e métodos, como o caso do professor que afirma: 
Revista Jurídica Trabalho e Desenvolvimento Humano Procuradoria Regional do Trabalho da 15a Região

"Após uma semana de aulas suspensas e treinamento intensivo online, retomamos as aulas e outras atividades acadêmicas por meio da plataforma Zoom. Estamos aos poucos aprendendo a realizar as muitas adaptações necessárias para o ensino remoto." Para além dos aprendizados, existem mudanças efetivas nas formas de gerenciamento de equipes, agora mediadas por ferramentas como o WhatsApp e por sistemas de segurança de conexão e produção como o VPN (Virtual Private Network).

Também a reportagem passa a ser reinventada à distância, sem meios de apuração presencial, os recursos que estão disponíveis passam pela Internet e assim, o repórter afirma: "Impedimento à apuração em campo." E há mesmo todo um exercício para manter pelo menos o mínimo de atividades presenciais, com todos os cuidados necessários, conforme relata outro repórter: “Entramos num esquema de plantão, onde só precisamos ir presencialmente na redação uma vez na semana. Apenas um repórter trabalha na rua por vez. Um pela manhã/tarde e outro pela tarde/noite. O restante trabalha de casa, num ritmo bem corrido de home office." Os enunciados desses profissionais atuam no sentido da produção de um discurso que enfatiza a necessidade de adaptação às novas condições frente à Covid-19, e eles e elas não medem esforços para manter seu trabalho em dia, aperfeiçoando o uso de ferramentas já usadas, mas agora imprescindíveis para o trabalho. A atividade industriosa ${ }^{10}$ de todo o ser humano demanda o uso integral de si, desde o planejamento de como se faz até o momento mesmo do fazer, do ato a realizar. Isso se denomina gestão de si no trabalho e para esse exercício também é necessária a gestão do outro, dos tempos, das entregas, dos envios do material produzido. Há um reinventar-se no trabalho, daí certo desconforto, cansaço e o sentido do estresse.

Para além da gestão das equipes de trabalho que necessitam readequar o ritmo e o relacionamento, há também que se realizar a gestão do ambiente e dos entes familiares. São muitos os enunciados que marcam a mudança da rotina também pela

\footnotetext{
${ }^{10}$ SCHWARTZ, Yves; DURRIVE, Louis. Trabalho e Ergologia: conversas sobre a atividade humana. Niterói: Eduff, 2007.
} 
Revista Jurídica Trabalho e Desenvolvimento Humano Procuradoria Regional do Trabalho da 15a Região

gestão dos filhos: "Agora trabalho em casa, o que dificulta a concentração com filho em casa, além do estresse maior e ansiedade por estar o tempo todo lendo, ouvindo e acompanhando informação sobre a Covid 19." Aqui o enunciador é subeditor de um veículo e, embora tenha sido deslocado para o home office, parece que o estresse aumentou devido às implicações óbvias da pandemia, mas, sobretudo, porque o espaço da casa é o espaço da família, e a presença do filho interfere na concentração necessária para o trabalho. Não é o filho que atrapalha, é o trabalho que está fora de lugar.

Também o publicitário, na função de atendimento, relata sua rotina destacando a presença do filho: "O meu trabalho, em relação à função, continua o mesmo. O que mudou foram que as relações se tornaram digitais, tanto com o cliente, quanto com a equipe da agência. $O$ maior impacto que senti foi o de trabalhar em casa junto com filho." O impacto de trabalhar em casa junto com o filho quer nos dizer algumas coisas, que talvez possamos inferir: impacta porque a criança requer a atenção dos pais; impacta porque trabalhar em casa precisa de espaço adequado, considerando e preservando o espaço da criança e do companheiro; impacta porque o trabalho em casa pode descarrilar o tempo, fazendo-nos atrelados ao trabalho e desfocados de outras atividades fundamentais para o convício em um lar. A vigilância e a disciplina para delimitar tempo de trabalho e tempo da família é um aprendizado que passa a ser fundamental nesse período. O estresse do convívio sem respeito ao tempo e ao espaço de cada um provoca desentendimentos, sofrimentos e pode gerar violência.

Há ainda enunciados que informam sobre a necessidade de reivindicar o direito ao afastamento social; e para os que precisam estar no local de trabalho, há necessidade de produtos de higiene e de proteção pessoal. Por outro lado, há empresas que garantiram o home office com equipamentos da empresa, para que softwares e sistemas de comunicação e controle possam permitir maior "normalidade" de condições para a produção.

Esses poucos enunciados selecionados entre os 557 respondentes da pesquisa revelam o esforço dos profissionais para manterem-se em atividade, para entregarem seu trabalho da melhor maneira possível, sobretudo porque o produto com o qual 
Revista Jurídica Trabalho e Desenvolvimento Humano Procuradoria Regional do Trabalho da 15a Região

trabalham é a informação, material de muito valor, quando tem qualidade, em momentos de crise e de risco à saúde pessoal e coletiva nesse caso de pandemia.

\section{HORAS DE TRABALHO DURANTE A PANDEMIA}

Solicitamos aos respondentes declarassem sobre a jornada semanal de trabalho que praticam normalmente e se a jornada de trabalho foi alterada, durante esse período de pandemia (Gráfico 6). As respostas surpreendem ao indicarem o número elevado de horas semanais trabalhadas em tempos normais, dado que merece um estudo à parte com o cruzamento dos dados sobre salário e vínculo empregatício. Nosso levantamento, nesse caso, não permite aprofundamentos, mas denota a constatação de que o volume de horas merece estudo específico. Ao compararmos os dados daqueles que tiveram jornadas ampliadas durante a pandemia e aqueles que tiveram jornadas reduzidas, verifica-se que o aumento do número de horas está entre 2 e 4 horas diárias, dado absolutamente representativo da alteração da jornada de trabalho e que certamente contribui para o aumento da produtividade. O acréscimo de tarefas a serem feitas e renormalizadas $^{11}$ e a ampliação da carga horária, devido a novos procedimentos de gestão de si e de outros no trabalho etc., aumentam a densificação do trabalho e o estresse. Mas há também aqueles que tiveram a carga de trabalho reduzida ou mesmo cortada (caso das reduções de 8h). Para aqueles com redução da jornada de 1 a 4 horas diárias, houve também redução salarial e ou de ganhos advindos de prestação de serviços.

\footnotetext{
${ }^{11}$ SCHWARTZ, Yves; DURRIVE, Louis. Trabalho e Ergologia: conversas sobre a atividade humana. Niterói: Eduff, 2007.
}

FIGARO, Roseli; BARROS, Janaina V.; SILVA, Naiana R.; CAMARGO, Camila A.; SILVA, Ana Flávia M.; MOLIANI, João Augusto; OLIVEIRA, Daniela Ferreira de. Como trabalham os comunicadores na pandemia da Covid-19? Revista Jurídica Trabalho e Desenvolvimento Humano, Campinas, EDIÇÃO ESPECIAL - DOSSIÊ COVID-19, p. 1-39, 2020. 


\section{Gráfico 6 - Carga horária alterada durante a pandemia}

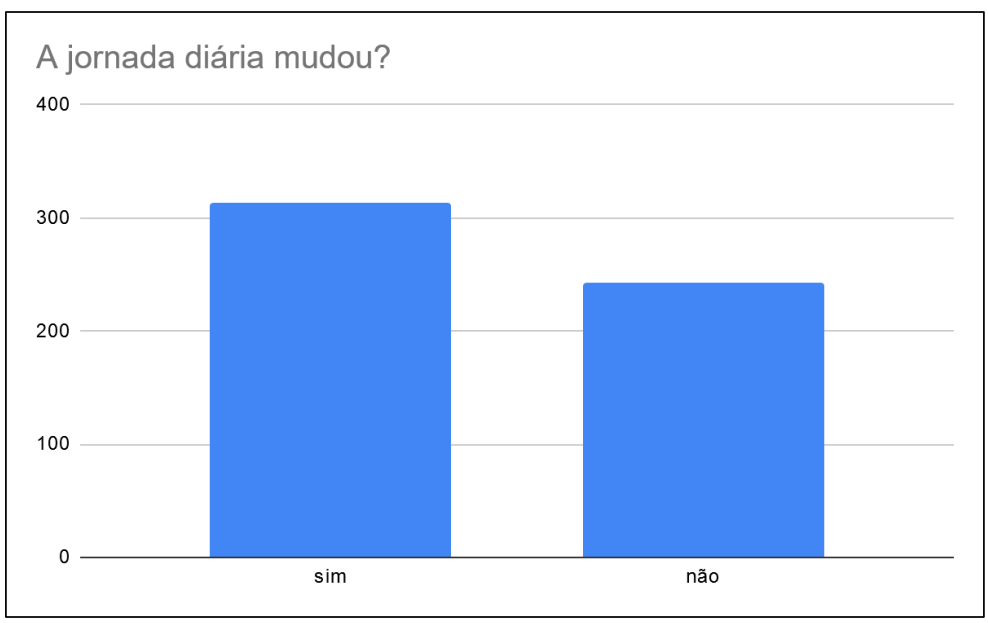

Fonte: Pesquisa CPCT/Como trabalham os comunicadores na pandemia da Covid-19?

Entre os respondentes, 307 tiveram jornadas de trabalho alteradas durante a pandemia. Entre eles, 250 tiveram acréscimo de horas em suas jornadas convencionais e 57 tiveram redução de horas em suas jornadas convencionais. Observando-se os dados de cada respondente, podemos detalhar os dados em que 27 pessoas reconhecem que a carga horária aumentou, mas não conseguem mensurar o aumento; 114 pessoas tiveram suas jornadas aumentadas de meia hora a duas horas e meia; 100 pessoas tiveram suas jornadas aumentadas de 3 a 6 horas, somando 40\%; e 09 pessoas tiveram suas jornadas aumentadas de 7 a 11 horas, somando 3,6\%.

Dentre os comunicadores cujas jornadas de trabalho sofreram mudanças durante a pandemia da Covid-19, 57 pessoas tiveram redução da carga horária, somando $10 \%$ da amostra dos comunicadores que tiveram suas jornadas de trabalho alteradas; 50 pessoas tiveram uma redução de carga horária de 1 a 4 horas, somando $88 \%$ dos comunicadores que tiveram suas cargas horárias de trabalho reduzidas; 07 pessoas tiveram uma redução de carga horária de 5 a 8 horas, somando 12,3\% dos comunicadores que tiveram suas cargas horárias de trabalho reduzidas.

A situação de pandemia da Covid-19 mexeu com a vida dos comunicadores, com a vida no trabalho e com a vida da família para além dos cuidados com a prevenção com o afastamento social. Houve para a maioria absoluta mudanças na jornada de trabalho, 
Revista Jurídica Trabalho e Desenvolvimento Humano Procuradoria Regional do Trabalho da 15a Região

compondo aumento de horas de atividade e, para um número menor, redução da jornada. Essas alterações incidem nas rotinas diárias do trabalhador e de sua família, exigem a reorganização da vida coletiva e implicam muitas vezes em intensificação do trabalho e em maior estresse e preocupações. Para aqueles cuja jornada de trabalho em termos de horas não foi afetada, as declarações assumem diferentes espectros: desde aqueles que estão habituados ao home office, mas agora têm de enfrentar o distanciamento social com a presença da família em casa e com a dificuldade de encontrar e/ou visitar clientes, até aqueles que estão pela primeira vez em home office e que, para cumprir a jornada de trabalho e fazer as entregas dentro dos prazos e com qualidade, têm de reorganizar suas rotinas e refazer a gestão de si e das equipes envolvidas. Há, em todos os casos, mudança e aumento das atividades a serem reorganizadas e geridas, tanto na perspectiva do ciclo de atividades como na perspectiva das relações de comunicação a serem renormalizadas. Outro aspecto que precisa ser verificado e passamos a discuti-lo é o que diz respeito ao ritmo de trabalho.

\section{TRABALHO EM HOME OFFICE E RITMO DE TRABALHO}

O contexto de pandemia da Covid-19 certamente acelerou a transição que alguns setores já ensaiavam de transmutar o local de trabalho para a residência do trabalhador. A situação de emergência em prol da saúde coletiva passou a justificar, desse modo, a forma improvisada que muitos tivemos de assumir do trabalho em casa. O improviso é de toda ordem: equipamentos inadequados, falta de softwares, falta de apoio técnico, falta de uma rotina organizada que se precisa inventar, inadequação de móveis e local não ergonômicos, lugar/espaço/ambiente inadequado, porque sobreposto à ambiência que pertence ao espaço privado da casa, do lar. O isolamento social também retira do trabalho algo fundamental que é a coletividade. A gestão do trabalho, o conhecimento, os processos, mesmo que não identificados como tal, são sempre geridos e necessitam do coletivo de trabalho. $\mathrm{O}$ aluno, a secretária, a fonte, $\mathrm{O}$ chefe, o colega de um setor ou de outro fazem parte do que Schwartz e Durrive 
Revista Jurídica Trabalho e Desenvolvimento Humano Procuradoria Regional do Trabalho da 15a Região

denominam de Entidades Relativamente Pertinentes (ERP) ${ }^{12}$. Essas Entidades, por vezes, parecem invisíveis, no entanto, garantem a sociabilidade e a realização do trabalho. Os manuais, os descritivos, o como fazer são normas antecedentes que, no ambiente de trabalho, são renormalizados no calor da atividade de trabalho, no seio do mundo do trabalho. Mudar a atividade laboral do local de trabalho para o local de moradia não é um simples deslocamento físico, geográfico. Existem aí implicações no fazer que alteram rotinas (mesmo que todo o tempo renormalizadas no coletivo) e que exigem uma reconstrução do mundo do trabalho, agora alargado para a casa, o lugar privado do trabalhador. Reconstituir a rotina e refazer as dimensões desse mundo do trabalho colocam para os que estão em atividade uma série de novos dilemas. Como reconstruir as relações com as Entidades Relativamente Pertinentes? Quais procedimentos permanecem válidos para a execução da atividade ou quais devem ser reorganizados? Como gerir a si próprio em termos das relações com o trabalho e com a casa? Como reconstruir a gestão de si em relação ao outro no trabalho em casa? Essas são algumas questões que merecem um estudo aprofundado, a partir da observação das situações de trabalho em casa. Aqui nos restringiremos a alguns apontamentos que os dados nos demandam.

\section{SOBRE O RITMO DE TRABALHO}

Quando perguntados sobre o ritmo de trabalho no contexto do isolamento social, devido à pandemia, $70 \%$ dos respondentes afirmam que o ritmo está um pouco mais pesado ou muito mais pesado. Os demais respondentes, conforme mostra a Tabela 1, informam que: não mudou nada, um pouco mais tranquilo ou muito mais tranquilo. As respostas estão diretamente vinculadas ao tipo de atividade que cada qual desempenha, à experiência anterior com o home office e mesmo à condição do micro empresário e do freelancer que já atuavam em casa.

\footnotetext{
${ }^{12}$ SCHWARTZ, Yves; DURRIVE, Louis. Trabalho e Ergologia: conversas sobre a atividade humana. Niterói: Eduff, 2007.
}

FIGARO, Roseli; BARROS, Janaina V.; SILVA, Naiana R.; CAMARGO, Camila A.; SILVA, Ana Flávia M.; MOLIANI, João Augusto; OLIVEIRA, Daniela Ferreira de. Como trabalham os comunicadores na pandemia da Covid-19? Revista Jurídica Trabalho e Desenvolvimento Humano, Campinas, EDIÇÃO ESPECIAL - DOSSIÊ COVID-19, p. 1-39, 2020. 
Revista Jurídica Trabalho e Desenvolvimento Humano Procuradoria Regional do Trabalho da 15a Região

Tabela 1 - Como você está se sentindo em relação ao ritmo de trabalho comparativamente ao período antes da pandemia?

\begin{tabular}{|l|l|}
\hline \multicolumn{1}{|c|}{ Ritmo de trabalho na pandemia } & Contagem de respondentes \\
\hline Estava e continua sem trabalho regular & 3 \\
\hline Muito mais pesado & 192 \\
\hline Muito mais tranquilo & 28 \\
\hline Não mudou nada & 48 \\
\hline Sem trabalhar (férias antecipadas, banco de horas, grupo de risco) & 3 \\
\hline Um pouco mais pesado & 198 \\
\hline Um pouco mais tranquilo & 85 \\
\hline Total Geral & $\mathbf{5 5 7}$ \\
\hline \multicolumn{1}{|c|}{ Fonte: Pesquisa CPCT/Como trabalham os comunicadores na pandemia da Covid-19? } \\
\hline
\end{tabular}

A temática da reconfiguração de tempo e do ritmo de trabalho com o home office incide em todas as atividades, porém é percebido de maneiras diferentes a depender da função e da responsabilidade que se tem no desempenho do trabalho. Para os repórteres de televisão, a jornada mista, ou seja, parte em casa, parte na redação ou na rua, além do agravante e do estresse da exposição, comporta a dubiedade de situações e das ausências de equipamentos, colegas e infraestrutura para a produção. Há diferenças de percepção do ritmo de trabalho por aqueles que exercem jornada mista, jornada no local de trabalho, jornada em home office. Em todas as situações, a marca do aumento do ritmo de trabalho durante a pandemia está declarada.

Entre os participantes da pesquisa é possível comprovar a quase totalidade da adesão ao trabalho remoto, seja de forma parcial ou integral. Para $80 \%$ dos respondentes (449), o home office é a realidade do trabalho durante a pandemia. Entretanto, para esses comunicadores, trabalhar em casa não significa trabalhar menos, pois $71,5 \%$ dos respondentes (321) percebem um aumento na carga de trabalho, sendo que 156 apontam que o trabalho está "um pouco mais pesado" e 165 que está "muito mais pesado".

No mesmo sentido, entre os profissionais que estão realizando jornada mista (61), 65,5\% dos respondentes (40), sinalizam um aumento na carga de trabalho. Desses, 23 afirmaram que o trabalho está "um pouco mais pesado" e 17 que está "muito mais pesado".

FIGARO, Roseli; BARROS, Janaina V.; SILVA, Naiana R.; CAMARGO, Camila A.; SILVA, Ana Flávia M.; MOLIANI, João Augusto; OLIVEIRA, Daniela Ferreira de. Como trabalham os comunicadores na pandemia da Covid-19? Revista Jurídica Trabalho e Desenvolvimento Humano, Campinas, EDIÇÃO ESPECIAL - DOSSIÊ COVID-19, p. 1-39, 2020. 
Revista Jurídica Trabalho e Desenvolvimento Humano Procuradoria Regional do Trabalho da 15a Região

Por fim, entre os comunicadores que não estão trabalhando em home office ou jornada mista (47), 60\% dos respondentes (28) percebem um aumento na carga de trabalho. Desses, 10 responderam que o trabalho está "um pouco mais pesado" e 18 apontaram que o trabalho está "muito mais pesado", no período da pandemia. Neste grupo, 3 dos respondentes apontam que estão sem trabalhar e 2 já estavam sem emprego antes da pandemia.

É imperativo destacar, nesse quadro de intensificação do ritmo de trabalho em home office, dois aspectos: primeiro, as tecnologias e, segundo, o maior número de horas dedicadas ao trabalho, pois, no espaço da casa não, se perde tempo com o transporte e com outras atividades e intervalos regulamentados, ou seja, os tempos mortos para o capital. O aumento da jornada de trabalho e a aceleração dos ritmos de trabalho são dois processos clássicos para a obtenção de maior produtividade e de mais valor, aumentando a lucratividade para o sistema do capital. Também é conhecimento clássico que a tecnologia no mundo do trabalho acelera processos e reduz a quantidade de trabalhadores necessária à medida que otimiza procedimentos no processo produtivo. Não é preciso recorrer a Marx e a outros economistas para fazer tais afirmações, elas estão no campo do conhecimento já comprovado, experienciado e vivido por milhões de trabalhadores, desde a implantação da grande indústria. Estamos experimentando, em tempo recorde, a reorganização do mundo do trabalho para atender a um novo paradigma industrioso: o da chamada economia 4.0. Os hardwares, os softwares, aplicativos, redes e todo o material pesado envolvido nessa larga transmutação (fios, cabos, antenas, satélites, minérios, terras-raras entre outros) compõem uma cadeia produtiva que demanda formação profissional, reorganização do mundo do trabalho e, sobretudo, reorganização da vida em sociedade: da casa ao espaço público. É nessa perspectiva que precisamos entender os processos de trabalho que estão sendo implementados com o distanciamento social (e mesmo antes dele) agora intensificados.

É nessa perspectiva também que olhamos para os dados sobre a propriedade dos meios de trabalho dos comunicadores (Gráfico 7). Possuir um computador, com 
capacidade de memória para conexão de internet capaz de suportar aplicativos, softwares específicos de edição e de transmissão, com câmera e áudio adequados não custa barato, é preciso fazer um investimento. É como a caixa de ferramenta de um trabalhador, sem ela não é possível produzir. No entanto, o custo é completamente custeado pelo ganho desse trabalhador que, convenhamos, conforme mostram os pisos salariais (nota 3) é bem insuficiente.

\section{Gráfico 7 - Meios para trabalho em home office}

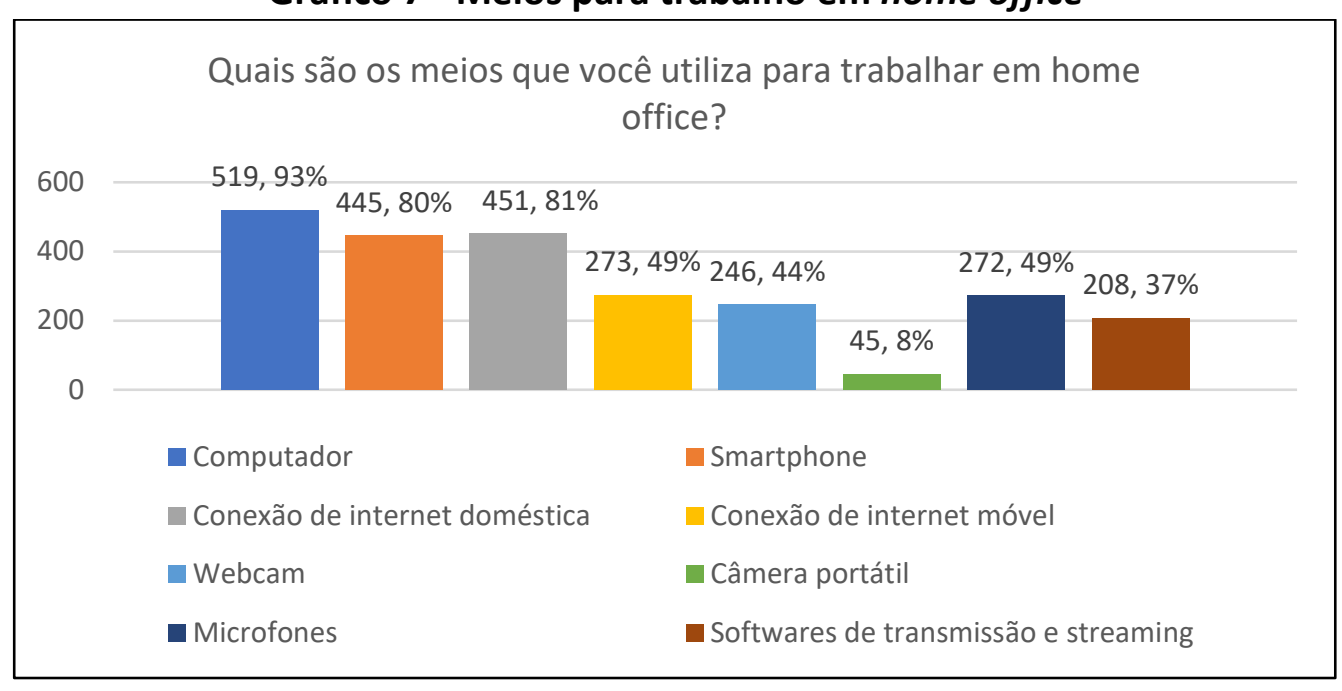

Fonte: Pesquisa CPCT/Como trabalham os Comunicadores na pandemia da Covid-19?

A realidade mostra que são os comunicadores que suprem sua caixa de ferramentas. Rara foi a empresa que forneceu equipamentos para o trabalho em home office nesse período, conforme mostra o Gráfico 8.

\section{Gráfico 8 - Propriedade dos meios de trabalho}

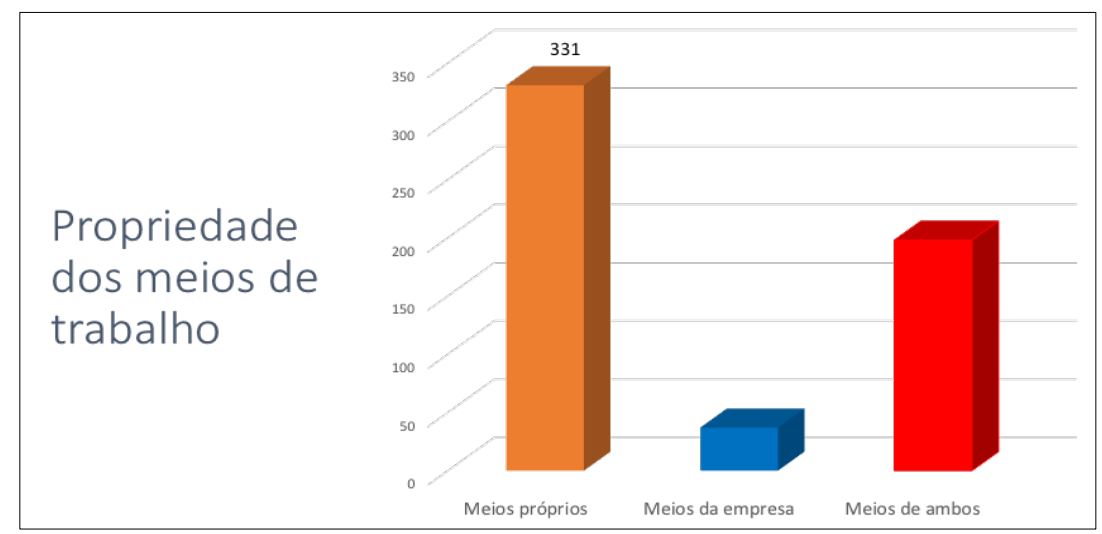

Fonte: Pesquisa CPCT/Como trabalham os Comunicadores na pandemia da Covid-19?

FIGARO, Roseli; BARROS, Janaina V.; SILVA, Naiana R.; CAMARGO, Camila A.; SILVA, Ana Flávia M.; MOLIANI, João Augusto; OLIVEIRA, Daniela Ferreira de. Como trabalham os comunicadores na pandemia da Covid-19? Revista Jurídica Trabalho e Desenvolvimento Humano, Campinas, EDIÇÃO ESPECIAL - DOSSIÊ COVID-19, p. 1-39, 2020. 
Revista Jurídica Trabalho e Desenvolvimento Humano Procuradoria Regional do Trabalho da 15a Região

Se os meios de produção para o trabalho representam uma caixa de ferramentas básica às expensas dos comunicadores, é preciso ter claro que esse ferramental: computador, conexão à internet, softwares etc. não bastam. Esses meios não o tornam dono do produto de seu trabalho, autonomia por muitos imaginada, sobretudo pelos que são autônomos, possuem $\mathrm{MEl}$, etc. ou seja, micro empresários de si mesmos. A conexão à internet, com ampla capacidade para transmissão e retransmissão é fundamental para a conexão às redes virtuais de gestão do trabalho. Sejam redes sistêmicas da própria empresa, sejam redes das empresas de plataforma como Google, Facebook, Amazon e os aplicativos WhatsApp, Trello, Instagram, Telegram, entre outros, é necessária a mediação deles para a realização da atividade, como mostra o Gráfico 9. Esses aplicativos acabam por ampliar suas funcionalidades, em razão do tipo de uso que a sociedade faz deles, ensinando os algoritmos a se aperfeiçoarem. Nesse exercício contínuo de produção, transmissão e difusão, os dados do trabalho coletivo vão compor a mina de dados a ser minerada e os dados compactados em formatos e perfis para voltar aos mercados. Esse mecanismo de capturar e retratar os dados e torná-los mercadoria para outras finalidades é que precisamos mais bem compreender o que significa em termos de valor e se podem gerar mais valor ${ }^{13}$. Isso quer dizer que todos nós trabalhamos para dois "patrões", aquele que contrata diretamente nosso trabalho, e o outro invisível, que por meio das lógicas de cookies (first-party cookies; cookies de terceiros e os fingerprintting são alguns atrevidos captadores de dados usados sobretudo pelo marketing) coletam os dados e trabalham com as informações pessoais e profissionais de todos nós. Além do mais, o home office amplia o uso da caixa de ferramentas de trabalho dos comunicadores para uma ambiência privada, aquela da

\footnotetext{
${ }^{13}$ Essa discussão tem sido feita de forma bastante acalorada por vários pesquisadores, podemos citar: Christian Fuchs, César Bolaño, Úrsula Huws e Ricardo Antunes. Nós ficamos com as referências de Huws que discute, em "A formação do cibertariado. Trabalho virtual em um mundo real", os diferentes enquadramentos do trabalho no nó da teoria valor-trabalho (HUWS, Ursula. A formação do cibertariado: trabalho virtual em um mundo real; tradução: Murilo van der Laan. Campinas: Edunicamp, 2017). Também Ricardo Antunes, no livro "O privilégio da servidão: O novo proletariado de serviços na era digital”, discute o tema, reafirma posições de Huws e adverte para a necessidade de compreendermos mais profundamente os mecanismos do capital para aprofundar a exploração e ampliar a extração de mais valor (ANTUNES, Ricardo. 0 privilégio da servidão: O novo proletariado de serviços na era digital. São Paulo: Boitempo, 2018).
}

FIGARO, Roseli; BARROS, Janaina V.; SILVA, Naiana R.; CAMARGO, Camila A.; SILVA, Ana Flávia M.; MOLIANI, João Augusto; OLIVEIRA, Daniela Ferreira de. Como trabalham os comunicadores na pandemia da Covid-19? Revista Jurídica Trabalho e Desenvolvimento Humano, Campinas, EDIÇÃO ESPECIAL - DOSSIÊ COVID-19, p. 1-39, 2020. 
Revista Jurídica Trabalho e Desenvolvimento Humano Procuradoria Regional do Trabalho da 15a Região

casa, onde estão outras pessoas, outras relações e circulam informações do âmbito privado. Tudo isso passa, com o home office, a fazer parte das informações captadas a serem mineradas e que ninguém pagou o trabalhador por elas, mas elas serão vendidas como mercadoria e alguém vai lucrar com isso.

\section{Gráfico 9 - Lugar virtual do trabalho - plataformas e aplicativos}

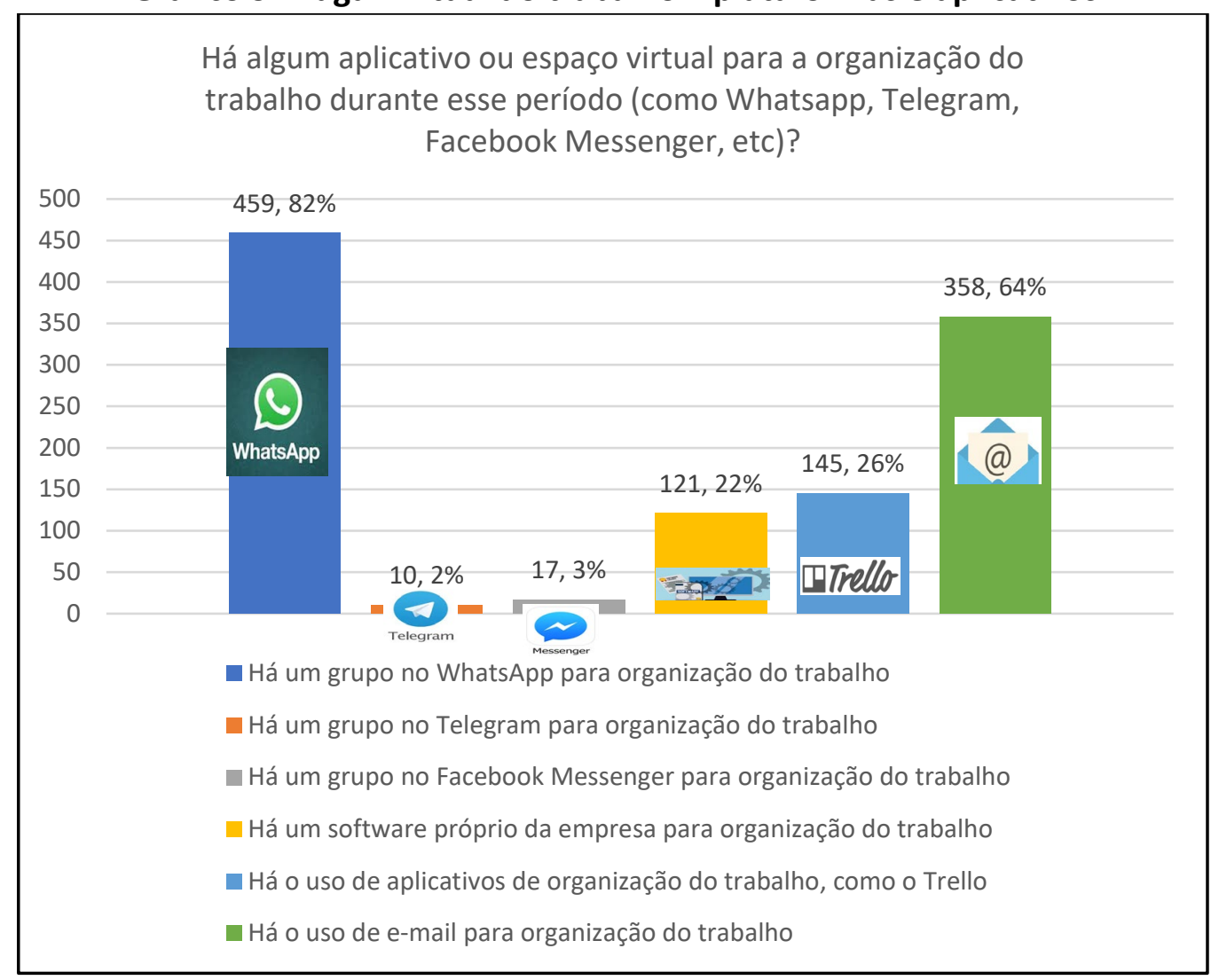

Fonte: Pesquisa CPCT/Como trabalham os Comunicadores na pandemia da Covid-19?

Conforme mostra o Gráfico 9, além dos equipamentos e da infraestrutura que o comunicador deve dispor em sua residência, torna-se obrigatório o uso de outros aplicativos e plataformas para realizar o trabalho. A gestão de equipes, a produção de textos, fotos, áudio, audiovisual e a transmissão e recepção de material contam com os aplicativos preferenciais dos comunicadores: WhatsApp, e-mail, Trello, Messenger, Telegram. Apenas uma parte pequena, $22 \%$, conta com software da própria empresa. Além da captura de nossos dados para outras ações mercadológicas, e até políticas, 0 que precisamos observar são as renormalizações que os comunicadores estão 
Revista Jurídica Trabalho e Desenvolvimento Humano Procuradoria Regional do Trabalho da 15a Região

realizando em seus procedimentos de atividades de trabalho, à medida que têm como complemento de seu ferramental os dispositivos comunicacionais ${ }^{14}$, que se instauram com o trabalho virtual. Estamos nos referindo aos procedimentos de contato com as equipes, como se dão o planejamento e as decisões sobre as tarefas a cada dia, por vezes, a cada hora, entre outras ações necessárias para a realização do trabalho. Alterase a noção tempo-espacial na e para a realização do trabalho. Há de fato aceleração do ritmo, da produtividade (gente almoçando em frente ao computador), há intensificação e alargamento das horas dedicadas ao trabalho e o aumento da jornada de trabalho da maioria dos respondentes como já apontamos.

O cruzamento dos dados aponta a intensificação do trabalho e o uso de aplicativos como fatores interdependentes. Ou seja, o ritmo das atividades é acelerado graças à mediação dos aplicativos, o que imediatamente leva à intensificação e a maior produtividade. Há também maior imersão, visto que as mensagens vindas via aplicativos demandam resposta imediata e assim faz-se um círculo virtuoso de aceleração, intensificação e produtividade. Ampliam-se também as horas à disposição do mundo do trabalho, pois o home office é um estar em casa disponível para o trabalho todo o tempo, graças à ubiquidade das redes sociais e seus aplicativos. Os dados mostram que os jornalistas são os que mais usam o aplicativo WhatsApp. Entre todos os respondentes, a maioria apontou o aumento na jornada de trabalho e também confirmou usar aplicativos mensageiros, como WhatsApp, Trello, e-mail, Messenger, Telegram.

O rodízio de trabalho para os que têm jornada mista foi a solução encontrada para manter, minimamente, equipes fazendo a cobertura in loco. Isso requer toda uma logística, não somente na distribuição da escala de trabalho, das pautas, mas também dos cuidados que se devem seguir frente à exposição em público. Equipamentos de proteção individual - EPI, como máscaras e luvas, passaram a ser fundamentais. A disponibilidade de fornecimento de álcool gel e de equipamentos sobressalentes de

\footnotetext{
${ }^{14}$ FIGARO, Roseli (org.). As relações de comunicação e as condições de produção no trabalho de jornalistas em arranjos econômicos alternativos às corporações de mídias. São Paulo: ECA-USP, 2018; MAINGUENEAU, Dominique. Análise de textos de comunicação. Tradução de Cecília P de Souza-e-Silva e Décio Rocha. São Paulo: Cortez, 2001.
}

FIGARO, Roseli; BARROS, Janaina V.; SILVA, Naiana R.; CAMARGO, Camila A.; SILVA, Ana Flávia M.; MOLIANI, João Augusto; OLIVEIRA, Daniela Ferreira de. Como trabalham os comunicadores na pandemia da Covid-19? Revista Jurídica Trabalho e Desenvolvimento Humano, Campinas, EDIÇÃO ESPECIAL - DOSSIÊ COVID-19, p. 1-39, 2020. 
Revista Jurídica Trabalho e Desenvolvimento Humano Procuradoria Regional do Trabalho da 15a Região

reportagem, como microfones e espumas para microfones, são elementos que não podem faltar ao comunicador que vai a campo.

Além dos aspectos já apontados sobre intensificação do trabalho e estresse, há que se considerar a redução das equipes e, em decorrência, o acúmulo de funções. 0 circuito das informações se intensificou porque há necessidade de se ampliar a produção para dar vasão às informações que chegam de fontes diversas, além daquelas tradicionais. Há também um repertório a ser aprendido e compreendido, que escapa das coberturas cotidianas. Todos esses elementos cobram maior atenção e envolvimento do comunicador. São interessantes os depoimentos que marcam a preocupação com a mudança nas formas de se fazer jornalismo. A distância social por causa da pandemia veio consolidar tendência bastante já sedimentada de se praticar jornalismo 'sentado', ou seja, a mediação do computador - com as ferramentas de busca e os bancos de dados e a agilidade dos aplicativos para colher entrevistas, depoimentos, contribuições do cidadão - substituiu de vez a apuração in loco. Esses métodos barateiam a produção, reduzem equipes e trazem, sobretudo para o jornalismo, a questão ética, à medida que a apuração é praticamente a posteriori à publicação ( $v i d e$ as constantes correções e atualizações) e a tarefa do repórter como um mediador no relato do acontecimento vai sendo substituída por outros agentes.

Nas falas dos participantes da pesquisa, há relatos sobre as precárias condições de infraestrutura para se realizar o trabalho em home office. Faltam softwares adequados, computadores com maior capacidade, há problemas de conexão com a internet, não há acesso a banco de dados da empresa, ou seja, elementos fundamentais para a realização do trabalho e cuja falta acaba por causar mais problemas de ansiedade, estresse e alargamento das horas de trabalho. Como já comentamos anteriormente, os custos do home office ficaram para o trabalhador. Se ele não tem a caixa de ferramentas adequada, o problema fica para ele/ela, esse pode ser um impeditivo para se cumprir o trabalho e perdê-lo, entre outras graves consequências. Há entre alguns setores da sociedade certa naturalização das condições de trabalho em home office, como se fosse

FIGARO, Roseli; BARROS, Janaina V.; SILVA, Naiana R.; CAMARGO, Camila A.; SILVA, Ana Flávia M.; MOLIANI, João Augusto; OLIVEIRA, Daniela Ferreira de. Como trabalham os comunicadores na pandemia da Covid-19? Revista Jurídica Trabalho e Desenvolvimento Humano, Campinas, EDIÇÃO ESPECIAL - DOSSIÊ COVID-19, p. 1-39, 2020. 
Revista Jurídica Trabalho e Desenvolvimento Humano Procuradoria Regional do Trabalho da 15a Região

absolutamente pertinente e obrigatoriamente normal que todos tenham recursos para os equipamentos necessários ao trabalho.

\section{A RELEVÂNCIA DO SERVIÇO PRESTADO, OS MEDOS, O QUE FALTA E O FUTURO}

A percepção do comunicador sobre a relevância de seu trabalho é sempre interessante de ser registrada e discutida. Nesse cenário de crise da saúde global, fizemos essa pergunta aos respondentes e os enunciados que recolhemos são bastante instigantes. Para ilustrar a forma das respostas, realizamos a seguinte nuvem de palavras ${ }^{15}$.

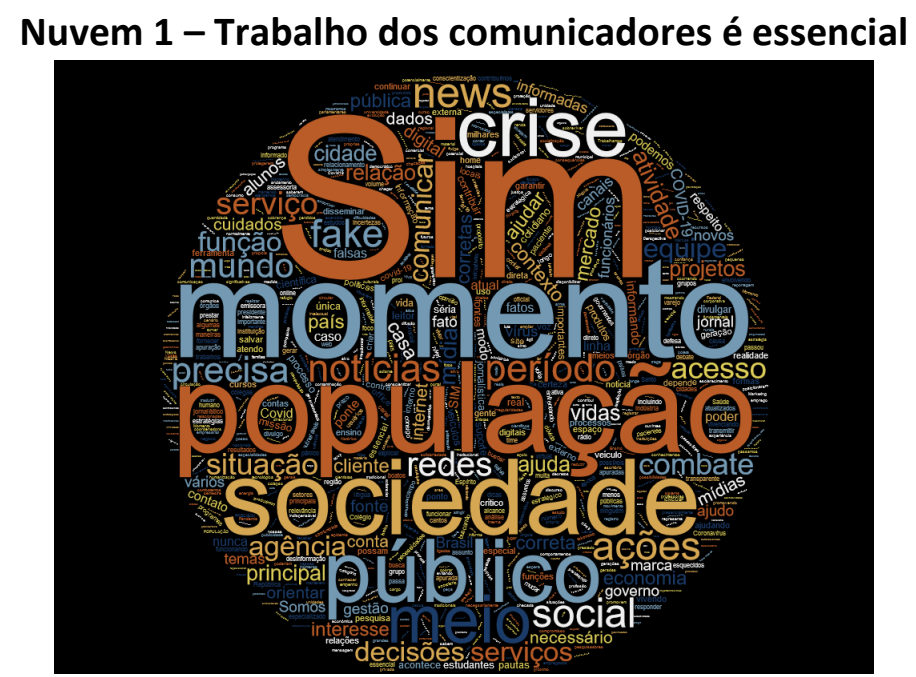

Fonte: Pesquisa CPCT/Como trabalham os Comunicadores na pandemia da Covid-19?

O “Sim" é majoritário, como ilustra a Nuvem 1. Os termos momento, população, sociedade, público e crise tematizam os eixos diretivos dos discursos desses comunicadores. A preocupação é com o coletivo. Para adentrarmos com mais propriedade nessa análise do porquê os comunicadores pensam ser sua atividade essencial, passamos ao registro analítico de alguns desses enunciados. Vale destacar o seguinte depoimento: "Sim, pela rapidez necessária na seleção e atualização das informações para o público. Só um jornalista consegue fazer isso com qualidade nessas

\footnotetext{
${ }^{15}$ Gerador de nuvem de palavras disponível em: www.nubedepalabras.es.
} 
Revista Jurídica Trabalho e Desenvolvimento Humano Procuradoria Regional do Trabalho da 15a Região

horas." Nesse enunciado estão presentes vários dos valores que norteiam a prática profissional: seleção, atualização, síntese, rapidez, qualidade e serviço ao público. Não se trata de fastfood, essas são habilidades que o profissional desenvolve e, aliadas ao chamado 'faro de notícia', que nada mais é do que a capacidade de observar, ser sensível e pesquisar, adquirir repertório, formam o ethos do profissional do jornalismo. Outra resposta que reitera a anterior: "Sim, a população merece e precisa receber informação de qualidade, principalmente agora sobre a pandemia."

É relevante destacar, nesses enunciados, que o discurso tem endereçamento de 'serviço ao público', produção de informação para orientar o cidadão. Observe-se a resposta de um analista de eventos: "Sim, trabalho com gestão de projetos sociais que ajudam a mitigar impactos da desigualdade social"; certamente, vinculado a alguma ONG ou instituição pública, preocupa-se com a manutenção da finalidade de seu trabalho. Essa assessora de comunicação afirma: "Sim, pois o trabalho do MP agora é no sentido de orientação e fiscalização das políticas públicas de combate ao novo coronavírus, bem como de orientação à população em geral sobre os cuidados que devem ser adotados e como devem denunciar irregularidades." O seu trabalho está diretamente vinculado aos direitos da cidadania, nesse sentido, a ação do profissional de comunicação não pode faltar em momentos de crise. Já a analista de marketing afirma: "Acredito que sim. Marketing, por ser um processo comunicacional, faz parte de diversas frentes para transmitir uma mensagem a um público desejado", ou seja, de forma geral, avaliza sua atividade como importante no direcionamento do público.

A consciência social é um aspecto fundamental na atividade do comunicador. Para o jornalista é até uma obrigação afirmar que a produção da informação é um bem maior para a sociedade, embora a lógica produtiva industrial e agora virtual priorizem o mercado e não a cidadania. A prova dessa afirmação é a lógica da monetização dos acessos e cliques que orientam a produção de pautas e as coberturas. Desse modo, não podemos ofuscar que o trabalho do jornalista também é marcado pelas determinações e interesses do mercado, nem sempre em consonância com os valores da informação para o bem-estar dos cidadãos.

FIGARO, Roseli; BARROS, Janaina V.; SILVA, Naiana R.; CAMARGO, Camila A.; SILVA, Ana Flávia M.; MOLIANI, João Augusto; OLIVEIRA, Daniela Ferreira de. Como trabalham os comunicadores na pandemia da Covid-19? Revista Jurídica Trabalho e Desenvolvimento Humano, Campinas, EDIÇÃO ESPECIAL - DOSSIÊ COVID-19, p. 1-39, 2020. 
Mas o que pode pensar um publicitário sobre sua atividade em um momento como o que estamos atravessando? Há também reflexões sobre isso nos enunciados que colhemos: "O trabalho com texto e comunicação, de um modo geral, é importante. No entanto, se formos pensar numa perspectiva de mercado e consumo, o trabalho publicitário é essencial para fazer conhecer os produtos e circular o negócio. Se formos pensar numa 'perspectiva social', tenho grandes dúvidas sobre a serventia, especialmente se levado em conta os artifícios ligados à persuasão; fazer as pessoas comprarem coisas que não precisam não é algo muito legal." Este outro profissional, na função de planejamento, não titubeia em afirmar: "Não. Comunicação Interna não é essencial para a sociedade." Essa consciência não os impede de continuar desempenhando suas atividades, mas demonstra discernimento e sensatez que, por vezes, escapam àqueles que têm responsabilidades claras em relação à gestão da empresa e do setor público. Esses são alguns destaques que fizemos para reiterar a sensata noção da relevância de seu trabalho que têm os comunicadores.

\section{O SENTIMENTO DOS COMUNICADORES NO TRABALHO}

O trabalho dos comunicadores durante a pandemia é acompanhado também por temores, medos e receios que incidem diretamente sobre suas rotinas de trabalho. Entre as aflições que possivelmente tiram o sono ou a paz de muitos jornalistas, publicitários, assessores, professores, relações públicas, dentre outros profissionais que participaram da pesquisa, está o medo do contágio pelo coronavírus. No Gráfico 10 é possível visualizar quais as cinco principais causas de temor nos participantes da pesquisa.

FIGARO, Roseli; BARROS, Janaina V.; SILVA, Naiana R.; CAMARGO, Camila A.; SILVA, Ana Flávia M.; MOLIANI, João Augusto; OLIVEIRA, Daniela Ferreira de. Como trabalham os comunicadores na pandemia da Covid-19? Revista Jurídica Trabalho e Desenvolvimento Humano, Campinas, EDIÇÃO ESPECIAL - DOSSIÊ COVID-19, p. 1-39, 2020. 


\section{Gráfico 10 - Principais medos dos comunicadores}

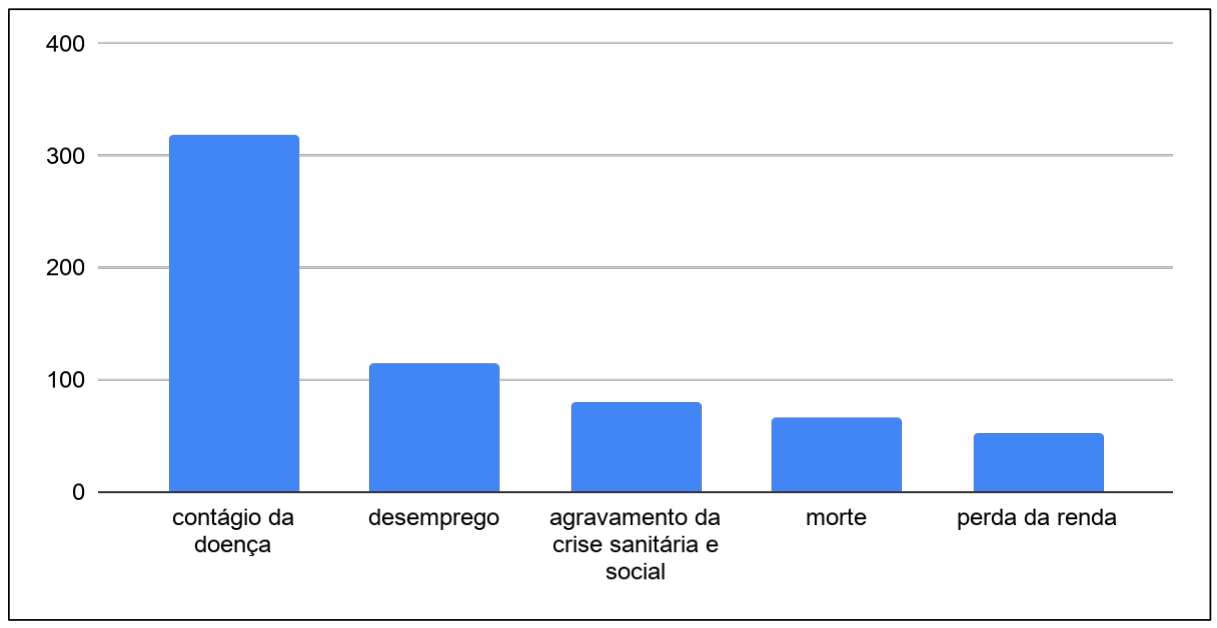

Fonte: Pesquisa CPCT/Como trabalham os comunicadores na pandemia da Covid-19?

Entre os respondentes, 323 deles, o equivalente a 57\% da nossa amostra, temem ficar doentes ou que seus familiares, amigos e colegas de trabalho também fiquem doentes. Era esperado que esse fosse o principal temor, afinal, muitas de nossas adequações, desde que a pandemia foi decretada, visam exatamente evitar o contágio. No mundo do trabalho, a adoção do trabalho remoto de forma massiva se apresentou exatamente como uma medida para minimizar a possibilidade de contágio.

A gravidade da pandemia faz com que outros temores ou medos dos comunicadores também se relacionem diretamente com o contágio da doença, como o terceiro item do gráfico: o medo do agravamento da crise sanitária e social. Nesse quesito, estão incluídos os temores mais coletivos, relativos à ineficácia das políticas de enfrentamento da pandemia em âmbitos locais e o temor de que as medidas adotadas pelo Governo Federal não colaborem para a melhoria das condições e sim agudizem o quadro geral da pandemia no Brasil.

É importante lembrar que a pesquisa foi encerrada no dia 30 de abril e, logo nos primeiros dias do mês de maio, houve o endurecimento das medidas de isolamento social em quase todo o Brasil, o que vem tornando esse temor dos comunicadores uma realidade. Ainda na esfera da saúde, a morte é outro medo dos profissionais. Eles têm mais medo de que os familiares e amigos morram do que deles próprios perderem a vida. 
Revista Jurídica Trabalho e Desenvolvimento Humano Procuradoria Regional do Trabalho da 15a Região

É válido observar que a crise desencadeada pela pandemia da Covid-19, apesar de ser de saúde pública, tem consequências em diferentes esferas sociais e os sentimentos de medo dos profissionais mostram exatamente as imbricações entre as diversas dimensões da crise. Sendo assim, o medo da morte relaciona-se diretamente com o medo de contágio e o medo do colapso do sistema de saúde, compondo uma tríade de temores relativos à saúde individual e coletiva dos comunicadores, visto que o Estado não tem atuado de forma coesa na orientação da população nem mesmo em garantir recursos aos sistema de saúde público.

Outra dimensão que aparece no gráfico versa sobre o trabalho e a sustentabilidade dos profissionais e de seus familiares. O desemprego aparece, portanto, como a segunda aflição mais citada pelos participantes da pesquisa, com 117 menções. Ou seja, $21 \%$ dos participantes da pesquisa temem perder seus empregos ou continuar desempregados.

E a perda da renda, apesar de ter sido mencionada apenas 53 vezes, pesa bastante na balança das condições materiais de vida. É preciso explicar que a renda aqui não se refere exclusivamente à redução dos salários dos trabalhadores, mas também às perdas de faturamento de agências e empresas. Até mesmo profissionais com vínculos estáveis citam esse temor em suas falas, pois a perda de renda da empresa pode implicar diretamente em demissões. Os proprietários de empresas de comunicação e os trabalhadores autônomos que vivem da prestação de serviços para clientes também citam esse temor de diminuição do faturamento.

Trabalho, pandemia, home office, casa, empresa, comunicação, informações, isolamento, tempo, funcionários são as palavras mais citadas quando se fala em experiência de trabalho na pandemia. Elas são as que mais aparecem, quantitativamente, e mostram um campo de semiose que nomeia o trabalho, a comunicação, a casa e home office como chaves de suas ações. Selecionamos, aleatoriamente, alguns depoimentos que são significativos da experiência e das preocupações desses profissionais.

FIGARO, Roseli; BARROS, Janaina V.; SILVA, Naiana R.; CAMARGO, Camila A.; SILVA, Ana Flávia M.; MOLIANI, João Augusto; OLIVEIRA, Daniela Ferreira de. Como trabalham os comunicadores na pandemia da Covid-19? Revista Jurídica Trabalho e Desenvolvimento Humano, Campinas, EDIÇÃO ESPECIAL - DOSSIÊ COVID-19, p. 1-39, 2020. 
Revista Jurídica Trabalho e Desenvolvimento Humano Procuradoria Regional do Trabalho da 15a Região

Os depoimentos trazem o dilema da dúvida, da incerteza. Cada qual à sua maneira reporta as dramáticas consequências da reorganização do trabalho em home office e as limitações desse tipo de distanciamento, sobretudo, quando se trata da cobertura jornalística. Nesses depoimentos, revelam-se comunicadores que atuam em diferentes frentes da atividade e em diferentes empresas e tipos de serviços. É instigante ler a declaração da comunicadora que presta assessoria de comunicação a planos de saúde e a preocupação dela em detalhar os cuidados para informar os usuários das clínicas médicas. Há mesmo uma fixação para a realização do trabalho. “Existe nossa própria pressão, por querer entregar um bom trabalho", declara.

Definitivamente, podemos afirmar que o uso dos aplicativos intensifica o trabalho, conforme mostram os dados e muitas das falas que podemos sintetizar na declaração: "Mas ao fazer o home office há uma sobrecarga(...)". Esse comunicador também se preocupa com a rotina de quem tem filhos em casa, sobretudo os menores. As mulheres ficam mais assoberbadas com as tarefas da casa, quando existem crianças. Há também a preocupação absolutamente pertinente com a segurança das informações que, agora no espaço do home office, sem as ferramentas adequadas de proteção, estão abertas a qualquer tipo de invasão, além daquela que já sabemos existir como lógica de monetização das empresas de plataforma. Essa será sem dúvida a grande questão do futuro. Palavra aliás que apareceu apenas 17 vezes nesses depoimentos, contra as mais de 800 vezes que aparece a palavra trabalho (trabalhadores, trabalhando, trabalhar).

Podemos afirmar que o campo semântico priorizado é o trabalho e a incerteza. A incerteza de se ter trabalho depois da pandemia, incerteza da situação econômica, incerteza de como se irá trabalhar, incerteza que reduz o potencial e a força da palavra futuro. A palavra risco também aparece e o risco é de contaminação, de demissão, de corte de salário, risco do colapso do sistema de saúde. Ou seja, risco também traz incerteza. Emociona o relato dessa comunicadora: “Minhas angústias estão ligadas à saudade do cotidiano que tinha que incluir vida social (...)" Saudade da vida que tinha, do cotidiano. Soa estranho falar em "saudade do cotidiano". É como se a vida estivesse suspensa, aguardando para ser vivida. A sensibilidade que sente e enuncia o mundo do

FIGARO, Roseli; BARROS, Janaina V.; SILVA, Naiana R.; CAMARGO, Camila A.; SILVA, Ana Flávia M.; MOLIANI, João Augusto; OLIVEIRA, Daniela Ferreira de. Como trabalham os comunicadores na pandemia da Covid-19? Revista Jurídica Trabalho e Desenvolvimento Humano, Campinas, EDIÇÃO ESPECIAL - DOSSIÊ COVID-19, p. 1-39, 2020. 
Revista Jurídica Trabalho e Desenvolvimento Humano Procuradoria Regional do Trabalho da 15a Região

trabalho como algo que lhe pertence, construído como eixo de relações de afetos que não podem, de uma hora para outra, serem substituídas pelas frias vídeo-reuniões.

\section{CONCLUSÕES}

A pesquisa "Como trabalham os comunicadores em tempos da pandemia da Covid-19?", realizada por meio do instrumento questionário misto, via formulário do Google, disponibilizado no período de 5 a 30 de abril de 2020, por meio do site e das redes sociais do Centro de Pesquisa em Comunicação e Trabalho - CPCT e por um conjunto de entidades profissionais e de pesquisa vinculadas às profissões do setor da comunicação, permite afirmar que o home office foi adotado por esses trabalhadores como forma de enfrentar o distanciamento social.

A maioria dos respondentes, do total de 557, é do gênero feminino e está na faixa etária entre 19 e 39 anos. A maioria também se declarou jornalista. São 12 setores de trabalho, sendo os mais declarados numericamente: mídia tradicional; assessoria de comunicação; agência de comunicação, marketing e publicidade; instituição de ensino, pesquisa e extensão; mídia alternativa/independente/comunitária/sindical; organizações não governamentais; e empresa privada, cuja finalidade não é a comunicação.

São poucas as empresas que supriram o home office com ferramentas adequadas para a continuidade do trabalho. A maioria absoluta diz utilizar seus próprios equipamentos e recursos para a realização do trabalho em home office. Aplicativos mensageiros como o WhatsApp, são usados para fazer o trabalho, tanto a gestão de equipes, como para o contato com fontes, entrevistas, videoconferências etc. O custo do uso de infraestrutura da residência do trabalhador ainda não foi computado, porque certamente as contas de energia elétrica, internet, telefone chegarão nos próximos meses. Também o custo com equipamentos, softwares fica na conta do trabalhador.

O aumento da jornada de trabalho foi apontado por um número bastante expressivo dos respondentes e a maioria identificou intensificação do ritmo de trabalho no período e no home office. Conforme foi detalhado nos itens anteriores, registra-se o

FIGARO, Roseli; BARROS, Janaina V.; SILVA, Naiana R.; CAMARGO, Camila A.; SILVA, Ana Flávia M.; MOLIANI, João Augusto; OLIVEIRA, Daniela Ferreira de. Como trabalham os comunicadores na pandemia da Covid-19? Revista Jurídica Trabalho e Desenvolvimento Humano, Campinas, EDIÇÃO ESPECIAL - DOSSIÊ COVID-19, p. 1-39, 2020. 
Revista Jurídica Trabalho e Desenvolvimento Humano Procuradoria Regional do Trabalho da 15a Região

empenho do comunicador em renormalizar suas atividades com a nova realidade do trabalho em casa. É preciso reconstruir as formas de trabalhar, como refazer as relações de comunicação quando o mundo do trabalho foi deslocado e desestruturado. Há um árduo empenho em reconstruir as dinâmicas das prescrições para o trabalho, refazer as relações com as entidades relativamente pertinentes, sem as quais é impossível trabalhar.

Quando falamos em trabalho remoto, estamos nos reportando àquele emprego cuja atividade está deslocada do local físico da empresa que contrata o trabalho. Ele não é novidade. Muitas funções são exercidas remotamente ao local de trabalho. A questão nova nesse quadro são as tecnologias digitais, ou seja, como os dispositivos comunicacionais permitem o trabalho remoto digital. A consideração que se faz aqui é a combinação do trabalho digital remoto com a necessidade de distanciamento social, devido à Covid-19. Um cenário perfeito para experimentar procedimentos que vinham sendo gestados de forma ponderada e que foram acelerados de forma desorganizada, sem o planejamento e a infraestrutura necessária para o trabalhador ser respeitado em seus direitos e condições de saúde física e mental.

Há, desde o final dos anos de 1990, um incremento no trabalho remoto. A legislação brasileira sobre o assunto é de 2011 (Lei 12.551/2011) e há até mesmo a Sociedade Brasileira de teletrabalho e teleatividades ${ }^{16}$, fundada em 1999. Desde então, tudo o que se discute está baseado na máxima de que o trabalho remoto e agora digital é mais lucrativo para a empresa, porque reduz número de trabalhadores, reduz custos operacionais, aumenta o controle do trabalho, a produtividade e reduz tempos mortos e direitos trabalhistas, individualiza e fragiliza a organização sindical e qualquer outro tipo de organização dos trabalhadores para garantia de direitos.

Por outro lado, faz-se uma série de afirmações positivadas, as quais nem sempre é possível confirmar. Por exemplo: de que o trabalho remoto digital aumenta a autonomia do trabalhador, reduz a poluição urbana e permite uma gestão mais racional do trânsito automotivo. Em duas décadas do século XXI, em que o trabalho remoto

\footnotetext{
${ }^{16}$ Site oficial: www.sobratt.org.br
} 
digital vem se instalando, os ganhos para a cidade e a gestão pública do trânsito e da poluição pouco alteraram a qualidade de vida dos cidadãos. A qualidade de vida dos trabalhadores, nível salarial e de empregabilidade também estão afeitos às ondas das crises cíclicas do capitalismo e muito menos à implementação de novidades no campo tecnológico, ao contrário, tais novidades têm sido submetidas à lógica da lucratividade e servido para fechar postos de emprego e precarizar ainda mais as relações capital trabalho, com perdas de direitos trabalhistas, queda salarial, quebra de regulamentação de várias profissões etc. Mas os ideólogos da bonança do trabalho remoto digital não param de aumentar seus ganhos e dividendos políticos. Toda sorte de parafernália discursiva ${ }^{17}$ é vendida como novidade a ser implantada pela gestão pública. Até mesmo um slogan já foi cunhado: 'teletrabalho: o novo normal'.

A irresponsabilidade social desses agentes institucionais é assustadora. Os usos que se faz das tecnologias e dos dispositivos comunicacionais servem para aprofundar a desigualdade social e aumentar a lucratividade de poucos. A experiência no período de distanciamento social devido à Covid-19 está sendo construída à base da improvisação e do aprofundamento da exploração dos trabalhadores. Faltam condições de infraestrutura, faltam procedimentos normativos e legais para regulamentar as condições de trabalho, faltam cuidados para a preservação das informações dos trabalhadores e das empresas. Falta uma política pública nacional para que não fiquemos a reboque dos operadores dos conglomerados de plataformas.

No caso dos comunicadores, nossa pesquisa demonstrou as limitações do exercício profissional na atual condição de trabalho remoto digital, como também provou a intensificação do trabalho e da jornada de trabalho. Elementos principais do aumento da lucratividade para as empresas de plataformas ${ }^{18}$. A desregulamentação da

\footnotetext{
17 Verificar no site http://www.sobratt.org.br/index.php/category/eventos/1-semestre-de-2020eventos/

a variedade de eventos promovida para fazer valer a inevitabilidade do sucesso do trabalho remoto digital.

18 GROHMANN, Rafael. Plataformização do trabalho: entre dataficação, financeirização e racionalidade neoliberal. Revista Eptic. vol. 22, n. 1, jan/abr. 2020. Disponível em: <https://seer.ufs.br/index.php/eptic/article/view/12188>. Acesso em: 25 jun. 2020.
} 
Revista Jurídica Trabalho e Desenvolvimento Humano Procuradoria Regional do Trabalho da 15a Região

profissão do setor da comunicação é um fator que aprofunda o quadro já problemático. Esse caminho é perigoso porque pode levar a caracterização de que o comunicador é um generalista produtor de conteúdo, com isso a fragmentação das atividades em micro tarefas facilita tornar o comunicador um assistente humano da inteligência algorítmica (Human Intelligence Task, ou Tarefa de Inteligência Humana) ${ }^{19}$. Não estamos operando com hipóteses, os fatos mostram como os algoritmos estão sendo programados para escrever notícias para os jornais, como a escrita SEO facilita a identificação de termos e a monetização da produção jornalística, como a programação de 'robôs' para ocupar o lugar de professores no ensino à distância está sendo aplicada exatamente agora, no período da crise da Covid-1920.

Essas são questões urgentes a serem discutidas para a formulação de estratégias de luta e resistência em prol do uso social das tecnologias digitais, em benefício da qualidade de vida e do trabalho decente, preparando-nos para passos mais decisivos na construção de condições dignas de vida para todos os trabalhadores.

\section{REFERÊNCIAS}

ANTUNES, Ricardo. 0 privilégio da servidão: O novo proletariado de serviços na era digital. São Paulo: Boitempo, 2018.

CASAQUI, Vander; LIMA, Manolita Correia; RIEGEL, Viviane (Org.). Trabalho em publicidade e propaganda. São Paulo: Atlas, 2011.

DOMENICI, Thiago. Após uso de robôs, Laureate agora demite professores de EAD. Publicado pela Agência Pública em 13 de maio de 2020. Disponível em: $<$ https://apublica.org/2020/05/apos-uso-de-robos-laureate-agora-demite-professoresde-ead/>Acesso em: 25 jun. 2020.

FEITOSA JÚNIOR, Alessandro. MTurk: quem são e o que fazem os brasileiros que estão na plataforma de "bicos" da Amazon. Publicado pela Gizmodo Brasil em 3 de

\footnotetext{
${ }^{19}$ FEITOSA JÚNIOR, Alessandro. MTurk: quem são e o que fazem os brasileiros que estão na plataforma de "bicos" da Amazon. Publicado pela Gizmodo Brasil em 3 de fevereiro de 2020. Disponível em: $<$ https://gizmodo.uol.com.br/amazon-mechanical-turk-plataforma-bicos-ia/>. Acesso em: 25 jun. 2020.

${ }^{20}$ DOMENICl, Thiago. Após uso de robôs, Laureate agora demite professores de EAD. Publicado pela Agência Pública em 13 de maio de 2020. Disponível em: <https://apublica.org/2020/05/apos-uso-derobos-laureate-agora-demite-professores-de-ead/>. Acesso em: 25 jun. 2020.
}

FIGARO, Roseli; BARROS, Janaina V.; SILVA, Naiana R.; CAMARGO, Camila A.; SILVA, Ana Flávia M.; MOLIANI, João Augusto; OLIVEIRA, Daniela Ferreira de. Como trabalham os comunicadores na pandemia da Covid-19? Revista Jurídica Trabalho e Desenvolvimento Humano, Campinas, EDIÇÃO ESPECIAL - DOSSIÊ COVID-19, p. 1-39, 2020. 
Revista Jurídica Trabalho e Desenvolvimento Humano Procuradoria Regional do Trabalho da 15a Região

fevereiro de 2020. Disponível em: https://gizmodo.uol.com.br/amazon-mechanicalturk-plataforma-bicos-ia/. Acesso em: 25 jun. 2020.

FIGARO, Roseli (org.). As relações de comunicação e as condições de produção no trabalho de jornalistas em arranjos econômicos alternativos às corporações de mídias. São Paulo: ECA-USP, 2018.

FIGARO, Roseli; NONATO, Cláudio; GROHMANN, Rafael (Org.). As mudanças no mundo do trabalho dos jornalistas. São Paulo: Salta, 2013.

G1 Rio. Jesus Chediak morre de Covid-19 no Rio de Janeiro. Publicado pelo G1 em 08 de maio de 2020. Disponível em: <https://g1.globo.com/ri/rio-dejaneiro/noticia/2020/05/08/jesus-chediak-morre-de-covid-19-no-rio-dejaneiro.ghtml>. Acesso em: 25 jun. 2020.

G1 RN. Jornalista de 74 anos morre com coronavírus em Mossoró. Publicado pelo G1 em 02 maio de 2020. Disponível em: <https://g1.globo.com/rn/rio-grande-donorte/noticia/2020/05/02/jornalista-de-74-anos-morre-com-covid-19-emmossoro.ghtml>. Acesso em: 25 jun. 2020.

GROHMANN, Rafael. Plataformização do trabalho: entre dataficação, financeirização e racionalidade neoliberal. Revista Eptic. vol. 22, n. 1, jan/abr. 2020. Disponível em: <https://seer.ufs.br/index.php/eptic/article/view/12188>. Acesso em: 25 jun. 2020.

HELOANI, Roberto. O Trabalho do Jornalista: estresse e qualidade de vida. São Paulo, Unicamp. Interações, v. 12, n. 22, pp. 171-198, 2006.

HUWS, Ursula. A formação do cibertariado: trabalho virtual em um mundo real; tradução: Murilo van der Laan. Campinas: Edunicamp, 2017.

LIMA, Cláudia do Carmo Nonato. Jornalistas, blogueiros, migrantes da comunicação: em busca de novos arranjos econômicos para o trabalho jornalístico com maior autonomia e liberdade de expressão. Tese de doutorado. Pós-graduação em Ciências da Comunicação, ECA-USP, 2015. Disponível em:

<https://www.teses.usp.br/teses/disponiveis/27/27152/tde-26062015-112522/ptbr.php>. Acesso em: 25 jun. 2020.

MAINGUENEAU, Dominique. Análise de textos de comunicação. Tradução de Cecília P de Souza-e-Silva e Décio Rocha. São Paulo: Cortez, 2001.

MICK, Jacques, LIMA, Samuel Pantoja. Perfil do jornalista brasileiro: características demográficas, políticas e do trabalho jornalístico em 2012. Florianópolis: Insular, 2013. 
MOLIANI, João Augusto. O trabalho em agências de comunicação: processos produtivos e densificação da atividade no jornalismo de rabo preso com o cliente. Tese de doutorado. Programa de Pós-graduação em Ciências da Comunicação. Universidade de São Paulo, 2020.

PERLINE, Gabriel. Antes de morrer por coronavírus, jornalista do SBT acusou emissora de negligência. Publicado pelo UOL em 13 abril de 2020. Disponível em:

$<$ https://noticiasdatv.uol.com.br/mobile/noticia/televisao/antes-de-morrer-porcoronavirus-jornalista-do-sbt-acusou-emissora-de-negligencia-35657>. Acesso em: 25 jun. 2020.

PITOMBO, João Pedro. Jornalista de afiliada da Globo no Maranhão morre. Publicado pela Folha de São Paulo em 22 de abril 2020. Disponível em:

<https://www1.folha.uol.com.br/cotidiano/2020/04/jornalista-de-afiliada-da-globono-maranhao-morre-de-covid-19.shtml>. Acesso em: 25 jun. 2020.

SCHWARTZ, Yves; DURRIVE, Louis. Trabalho e Ergologia: conversas sobre a atividade humana. Niterói: Eduff, 2007. 